
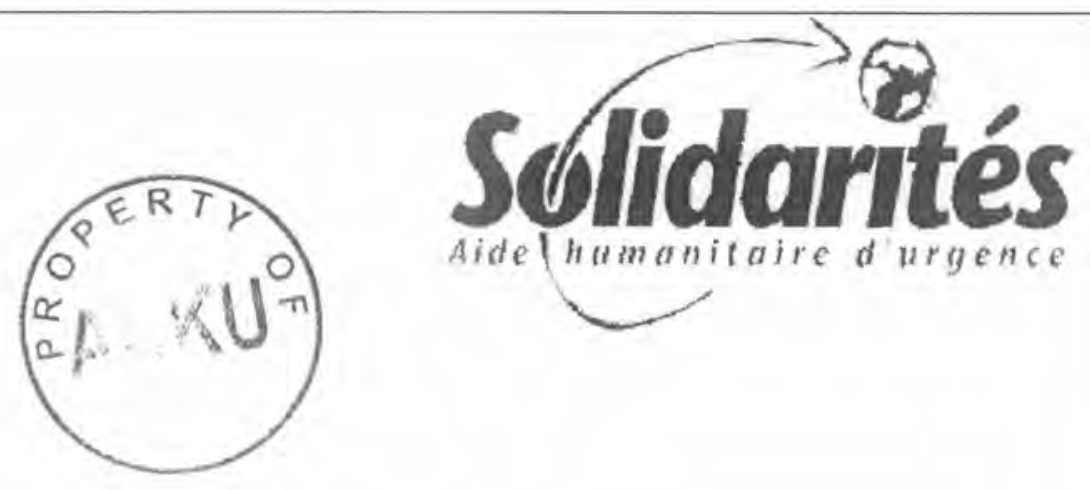

\title{
Trade exchanges survey in Yakawalang district
}

Yakawlang district, Bamyan province, Afghanistan

April-may 2005
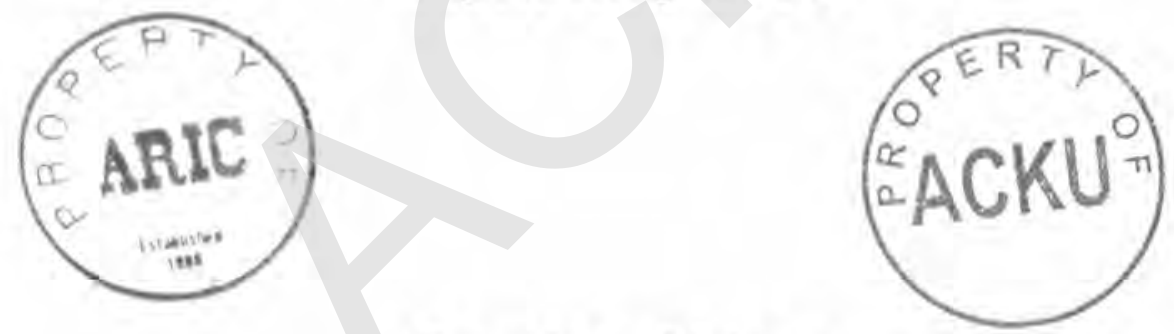

Damien Chiron

Agronomist 


\section{Contents}

1. Introduction

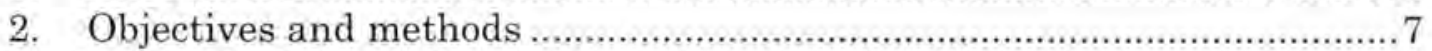

3. Main results,

3.1. Background concerning agriculture ……………......................... 8

3.2. Local production and imported goods ………..................................... 11

3.2.1. The local production............................................................... 11

3.2.2. The imported goods to Yakawland district................................... 12

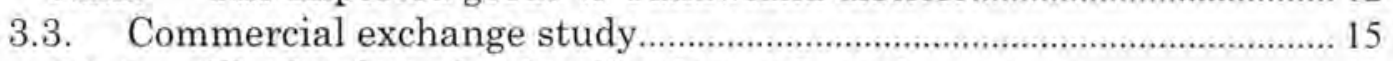

3.3.1. The local market localisation and market access........................... 15

3.3.2. The organisation and the links between markets........................ 20

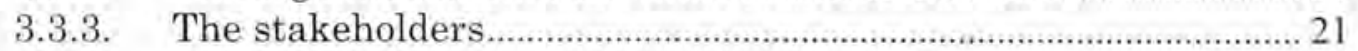

3.3.4. Relationships between the stakeholders ...................................... 25

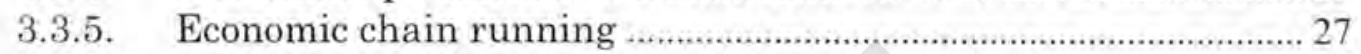

3.3.5.1. The commercials exchanges according to goods ........................ 27

3.3.5.2. The prices of the main exchanged goods …............................. 35

3.4. The funding system of the commercial exchanges ……........................ 39

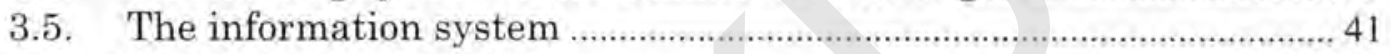

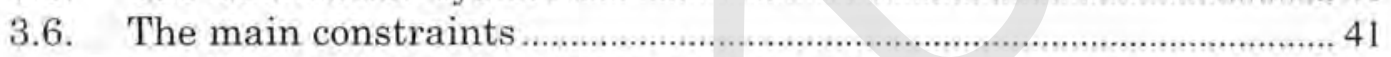

3.6.1. The road and the transportation costs........................................42

3.6.2. The currency rate exchange between afghani and Pakistani rupee 43

3.6.3. The inputs price fluctuation …........................................................ 44

3.6.4. The seasonality phenomenon and the weak storage capacity.... 44

3.6.5. The lack of cash and the farmer debt burden ............................. 45

3.6.6. The lack of information with Kabul market................................ 46

3.6.7. The lack of knowledge where to sell and buy in Kabul................ 47

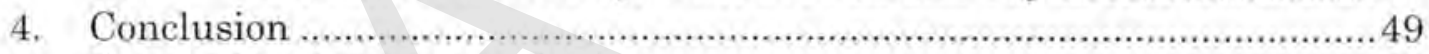

5. Proposal and recommendations ……………....................................... 49

5.1. Individual and/or collective potato storage...................................... 50

5.2. Collective purchases and collective point depot ………........................51

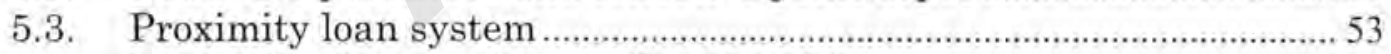

5.4. Marketing information services (M.I.S.) …………………………….....5 54

5.5. Agreement between producers and traders......................................... 58

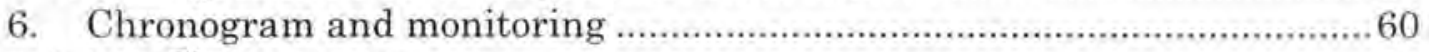

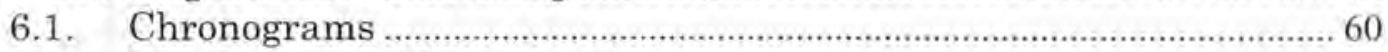

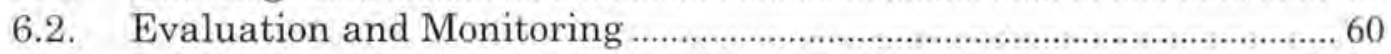

6.2.1. Individual and/or collective potato storage...................................... 61

6.2.2. Collective purchases and collective point depot ……………............63

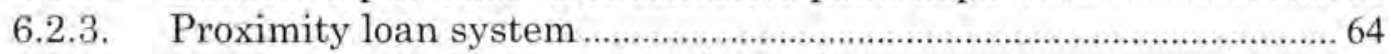

6.2.4. Market information services (M.I.S.) ……..................................... 65

6.2.5. Agreement between producers and traders

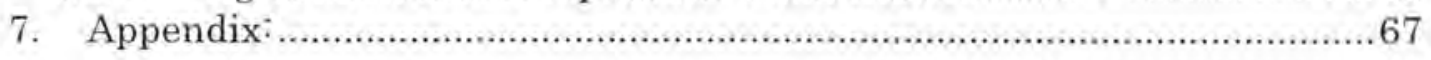


Commercial exchanges study - Yakawlang district - April/May 2005

Solidarités

8. Bibliography

68

3 


\section{Table of illustrations}

Figure 1: Crop calendar of the Yakawlang district...................................... 10

Figure 2: Localisation of the markets and the surveyed villages................... 16

Figure 3: Perception of a spatial market organisation ...............................21

Figure 4: Agro-ecologic map of Yakawlang .............................................24

Figure 5: Price fluctuation of the farm products in the Nayak Bazaar ........... 35

Figure 6: Local product gross margin made by farmers and shop keepers of

Nayak Bazaar........................................................................... 35

Figure 8: Input price and gross margins made by the shop keepers of Nayak

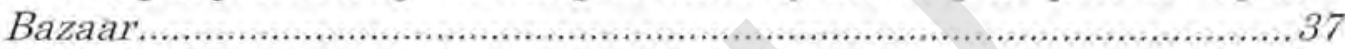

Figure 9: White urea price distribution (data from the shop keepers of Nayak

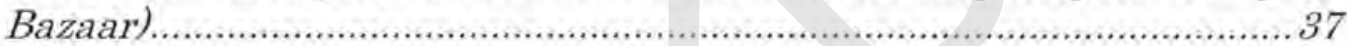

Figure 10: Seeds price and margin made by the shop keeper of Nayak Bazzar

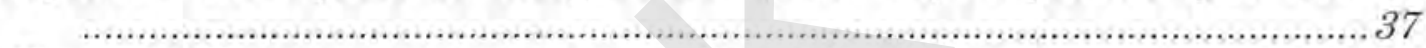

Figure 11: Transportation costs according to the distance..........................42

Figure 12: Currency rate fluctuation and cash needs ...............................4. 


\section{Introduction}

Afghanistan is an extremely poor, landlocked country, highly dependent on farming and livestock raising (agriculture: $53 \%$ GDP sector; labour force by occupation: $68 \%$ ). After two decades of war, the economic considerations start thanks to the humanitarian helps but it still stays weak and could be threaten by the political troubles. During the conflicts, one-third of the population fled the country, with Pakistan and Iran sheltering a combined peak of more than 6 million refugees. In early 1999, 1.2 million Afghan refugees remained in Pakistan and about 1.4 million in Iran ${ }^{\text {? }}$.

Gross domestic product has fallen substantially over the past 20 years because of the loss of labour and capital and the disruption of trade and transport. The majority of the population continues to suffer from insufficient food, clothing, housing, and medical care.

The new government era lets develop a liberalism system after the decades of war, the "collectivism system" and the population exodus. The currency rate reflects the free market exchange rates and inflation remains a serious problem throughout the country.

Afghanistan is composed of 2 geographical regions: the low land region around the high land region. The low land region corresponds to large plains where wheat, pulses and rice grow as well as fruit trees and vegetables near urban centres. In opposite, the high land region is a mountainous area where the wheat and barley grow with difficulties due to a severe winter. The Yakawlang district, the studied zone, belongs to these enclosed mountainous areas where the cold winter stops the farm activities.

The Yakawlang district is a valley composed of Hazara people (see the appendix 2.1, and appendix 2.2.). It is characterized by villages of farmers (mainly near the Yakawlang plain or in the sub valley) and by villages of stock breeders settled in the slope valley. As the population depends on the farm and the livestock activities, the marketing exchanges are reduced or stopped during the winter time.

\footnotetext{
hitp://www.theodora,com/wfbcurrent/afghamstan/
} 
Concerned by the current population movement, the agricultural potential of the Yakawlang valley and the poverty stating in the district, the French emergency NGO, Solidarités, built a 3 years rural development project EU funded in the Yakawlang district: "Rehabilitation of central region rural production systems". The specific objectives of this project are:

- the rehabilitation of the rural infrastructures

- the technical innovation support of the cropping system

- the commercial exchange support

- the micro-project development

This project aims to support the families (90\% are farmers and breeders) and also tries to develop the post harvesting chain thanks to the marketing improvement of the local production.

Considering the low commercial trade exchange during the winter and the agronomic potentiality of the Yakawlang valley, Solidarites needs to study the input and output exchanges to improve the commercial exchanges and to support the private sector and the rural development.

Given this situation, Solidarités requires a commercial trade exchange study in order to:

- Identify the stakeholders of the commercial trade exchange

- Determine the input and output exchanges

- Analyse the chain operating

- Identify the main constraints

At the end of the chain analysis study, some recommendations must improve the commercial trade exchange following by a monitoring schedule and a method to control the chain improvement.

Individual and collective interviews with a participatory approach allowed us to perform the chain analysis study and to identify the main constraints. Then, feedback to farmers, shop keepers and transporters permitted to establish their priorities and their challenges for a sustainable marketing development project.

This paper resumes the main results of the cham analysis after 30 days in Afghanistan, announces some proposals and proposes some recommendations for the following years of the Yakawlang district project. 


\section{Objectives and methods}

Solidarités is managing the EU funded "Rehabilitation of central region rural production systems" project for 3 years in the Yakawlang district. The components of this project are:

- The infrastructure rehabilitation

- the training support

- the trade exchange empowerment

- micro project development

The chain analysis study depends on the trade exchange support component. The aim of this survey is to understand how do the commercial exchanges operate, where the constraints are and how can the project improve the commercial exchanges. By this way, 20 days on the fields allowed us to make interviews in selected villages:

-6 villages of farmers,

- 5 villages of stock breeders,

- 4 small local markets

- 4 local markets

- the local authorities

The itinerary is presented in the appendix 6 .

The criteria to select the villages were:

- the production system tendencies of the villages: villages composed of more stock breeders or of more farmers

- the distance from markets: close, or far from a local market.

During this survey, the commercial exchanges officer of the project and the translator help me to get contacts with villagers. The first step consisted in the presentation of the survey to the Solidaritiés team and to the local authority (only a DAAH representative was present). Then, the approach was divided in 3 steps:

- the first one corresponding to individual surveys with farmers, breeders, shop keepers and transporters. Farmers and breeders were met in the villages, the shop keepers and the transporters in the markets.

- then a collective meeting with 3 to 5 interviewed people.

- at last, a collective meeting with the village community. 
It permitted to have the individual comments and to identify the individual constraints. The collective meetings allowed to collect the collectives constraints and to classify the village priorities. During these meetings, we tried to induce the villagers to discuss how they could improve these constraints.

After these individual and collective meetings, we invited some farmers, some shop keepers, some transporters and the local authority, the governor himself. Unfortunately, the DAAH representatives were absents. This feedback presented the commercial exchange stating and which has allowed to discuss and to debate about the commercial exchanges. It also permitted to bring together the stakeholders ant to discuss about their problems.

Then, in a second 6 days' period, the market of Bamyan (3 days) and of Kabul ( 3 days) were studied. International institutions (FAO) and NGOs (BRAC, AKDN, FINCA, IFDC) were met in order to get information regarding the markets. It also permitted us to discuss about the recommendation viability to decrease the risk of failures.

\section{Main results}

\subsection{Background concerning agriculture}

The Yakawlang district is composed of Hazart people (around 124,000 citizens, 16,040 families ${ }^{2}$ ) who are all dependant on the agricultural and livestock activities. $4 \%$ of the population is landless whereas around $95 \%$ of them are farmers as well as stock breeders ; but villages of breeders and villages of farmers can be identified according to the village settlement. The villages of breeders are mainly on the mountainous area whereas the villages of farmers are in plains. However, the downstream of the Shaman plain is a grazing land because of floods and soil salinisation. These two phenomena seem to decrease the crop land as well as the crop yield.

It is important to remind that the yakawlang district suffered of drought between 2001 and 2002. These 2 years had a large impact on the families. They were obliged to sell their livestock and to buy basic needs to survive.

\footnotetext{
${ }^{2}$ UNHCR, 2002. UNHCR Sub-Office Central Region, District Profile-Yakawlang district; 18/9/2002.
} 
The region produces mainly wheat (winter and spring wheat, around $80 \%$ of the familial cultivated land), barley and potato as cash crop. There is no individual tractor and no auto-mechanic equipments except the threshing machine introduced by Solidarités last year. One farm cooperative (located in Dend e Amir) manage 4 tractors and equipment for 1000 families since last year, but the cooperative seems to have problems (no drivers, spare part logistics issues, etc) despite the farmers will. The donkey is the main transportation means due to the sloppy sides and the flood periods during the months of April and May.

The families rear goats, sheep and cows. The animals stay in the yard during the winter and move to mountainous area for pastures from spring to autumn.

The activities between males and females are clearly separated: the field activities are practiced by men (ploughing, sowing, irrigating, harvesting) except the weed control. Women manage the herd with children. The women activities focus on the animal production (milking, feeding, wool handicraft, butter and krout making.,.).

Given the severe and long winter season ( 5 to 6 months), there is only one harvest period during the year. The following production calendar illustrates this period:

\begin{tabular}{|c|c|c|c|c|c|c|c|c|c|c|c|c|}
\hline & JAN & FEB & MAR & APR & MAY & JUN & JUL & AUG & SEP & OCT & NOV & DEC \\
\hline WHEAT & & & & 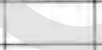 & 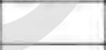 & & & & hhhhh & hhsss & & \\
\hline \multirow{2}{*}{ BARLEY } & & & + & & & & & hihtihh & hiss & & & \\
\hline & & & 2 & 8 & & & & & & & & \\
\hline PEA & & & & & & & & & hhhh & ssss & & \\
\hline CLOVER & & & & ssss & & & & & hahth & ssss & & \\
\hline LENTIL & & & & & & & & & fihtih & ssss & & \\
\hline KROL & & & & & & & & & hhhh & ssss & & \\
\hline \multirow[t]{2}{*}{ WITCH } & & & & & & & & hihhi & hhhh & ssss & & \\
\hline & & & & & & & & & & & & \\
\hline \multirow[t]{2}{*}{ РОTATO } & & & & & & & & & hhhh & hinss & & \\
\hline & & & & & & & & & & & & \\
\hline \multirow[t]{2}{*}{ LUCERN } & & & & ssss & & & & & hahs & ssss & & \\
\hline & & & & & & & & & & & & \\
\hline APRICOT & & & & & & & & hhhh & & ssss & & \\
\hline \multirow[t]{2}{*}{ WOOD } & & & & hiss & & & & & hiss & ssss & & \\
\hline & & & & & & & & & & & & \\
\hline KROUT & & & & & & & & & & hiss & & \\
\hline BUTTER & & & & & & & & & hiss & ssss & & \\
\hline LEATHER & ssss & & & & & & & & & & & \\
\hline
\end{tabular}




\begin{tabular}{|l|l|l|l|l|l|l|l|l|l|l|l|l|} 
ANIMAL IN LIVE & & ssss & & & & & & ssss & ssss & & \\
\hline WOOL & nhhh & & & & & hhhh & & & & ssss & & \\
\hline $\begin{array}{c}h \text { i harvest } \\
\text { s: sell }\end{array}$ & & & & & & & & & & & & \\
\hline
\end{tabular}

Figure 1: Crop calendar of the Yakawlang district

Regarding this above calendar, we conclude that the farmers are busy during September to October. After selling their production in autumn, the farmers must manage the familial budget for all the year. The brief household survey shows that a standard family needs some cash in April and in May (sowing costs, fertilizers costs), then in September and in October (threshing costs, winter fertilizers costs, food for winter). 


\subsection{Local production and imported goods}

\subsubsection{The local production}

a) The agricultural production

The agricultural production can be divided in 4 categories: the staple food production, the crop for sale production, the cash crop production and the fodder production.

- The staple food production: it is mainly composed of winter and spring wheat and barley. These cultivations hold the total rainfed area fields and around $75 \%$ of the irrigated area fields. The production is around 14,600 tons for all the yakawland district. (95\% of the 15,400 landowner families of Yakawland district have 0.4 ha in rainfed with $1 \mathrm{t} / \mathrm{ha}$ and 0.3 ha under irrigation with $2 \mathrm{t} / \mathrm{ha}$ ).

- The crop for sale production is mainly composed of pulses: pea, chickpea, vetch, lentil and "klol" (a sort of small green pea). Around the $3 / 4$ of the production are sold to Kabul first and also to Nayak. Several farmers are more or less specialized in the pulses production, but the cultivated area are under the cereals area.

- The cash crop is composed of potatoes. The potato cultivated area is around 0,1 ha/family and approximately 1 on 2 family produces with average yield of 15 to 20 tons/ha, that is around 11,500 to 15,400 tons for the yakawland district.

- The fodder production is composed of lucern, clover and natural grass productions. The first one is cultivated in the villages of breeders. The lucern cultivation is not well developed because of the lack of agricultural land, the water requirement and the long cycle. As the grass production is concerned, the Shaman plain is recovered of natural grass which can be cut and sold by the users. Therefore, the plain access is controlled by villagers and a local committee.

b) The livestock production

Sheep, cows and goats productions graze in the mountainous area during summer whereas the animals can pasture in the valley in spring and in autumn, In winter the animals are housing and feed with lucern, natural grass and horny grass from the mountainous area. 
In spring and in autumn, the living animals are sold to traders mainly from Kabul. In autumn and in winter the animal are milked which permits to produce butter for the self-consumption. With the lactoserum, the women produce the "krout" which corresponds to a kind of dried cheese without fats. This production is sold to the local market and in Kabul.

Sheeps are usually sheared 1 or 2 times per year providing wool either for local handicraft (carpets, blankets) or to sell to Kabul.

The chicken and the egg productions are not practiced because of the difficulties to breed chicken (cold winter, hot summer, problem of poultry food and eggs conservation).

Cows, donkeys and horses are used for transportation and field works.

c) The fruits production

The downstream valley of Yakawland produces some apricot fruits. The fruits and the fruit almonds are usually for the self-consumption and the fruits surplus are dried to be stored either for self-consumption or for sale. We mention that fruit garden are recently planted near the shaman plain.

d) The wood production

Poplars are usually planted along the irrigation canals and in the large riverbed. As above, the poplar production is increasing because of the wood needs for building (more shelters, more security, more projects etc). All the more, the poplar wood is expensive (a stem of 4 years costs $350 \mathrm{afg}$, that is 7USD) and can consist in saving production.

At the end, the local production is mainly for the self-consumption except the potatoes, the surplus of pulses, the krout and on the lower level the wool. Dried apricot production is too low to be mentioned as a "cash" crop. The poplar wood can become an interesting cash crop given the market trends.

\subsubsection{The imported goods to Yakawland district}

a) The fresh food:

The agricultural products can be divided in 3 categories: 
- The goods which are not perishable. These are rice (3 to 4 qualities), wheat, pulses (lentils, bean, chickpea etc) bought in Kabul but which come from Pakistan or from another production area of Afghanistan.

Dried fruits (apricot, raisin, walnut and almond) are bought in Kabul but are produced in the North East of Afghanistan and from Pakistan for ground nuts.

- The low perishable goods are mainly tubers like potatoes, onions, turnips, carrots.

- The spices and condiments like tomato power, pepper, salt in rock and tea etc.

The perishable goods like cabbage, tomato, and fresh fruits (bananas, medears, pears, apples, water melons, oranges, etc) are not on the Nayak market but only on the Bamyan one. The perishable goods depend on the season and the seasonality phenomenon is high. In Bamyan market, the rotten goods are frequent given the merchandises origin (Pakistan for oranges and bananas, East of Afghanistan for the vegetable, water melon, apples, pear). Given the enclosed Yakawlang district compare to Bamyan district, these perishable goods would be more rotten and so no shop keepers take risk to provide some in Nayak.

b) The inputs for the farmers

These imported inputs usually come from Kabul but are made in Pakistan, China, USA, Turkmenistan or Afghanistan. These are mainly fertilizers (white and black urea, DAP nitrophas), herbicides (2-4D), fungicide (carboxin, vitavax), medicines for animals (vaccine by drops and by infection, tablets) and then the farm tools (spade, rake and yoke).

The most used fertilizer is urea. The quality and the price of urea bag fluctuate a lot according to the farmers and the shop keepers; that is a break for the crop production development. Farmers also mention that the demand is higher than the supply and they complain about the urea and other fertilizers availability.

The quality of seeds (wheat, clover, vegetables) varies a lot and the farmers hesitate to pay for costly questionable seeds.

Some breeders mention also the ageing of several animal medicines. 
c) The manufactured products

It corresponds mainly to:

- for food: oil, sugar, eggs, biscuits, cake, sweets etc.

- for domestic purposes: soap, shoes, towel, and kitchen tools etc

- fuel in barrel of 250L

These manufactured goods are basic needs. 


\subsection{Commercial exchange study}

\subsubsection{The local market localisation and market access}

3 local markets (Nayak, Daga and Dares Chach) and 5 intermediate local markets (Maruff, Share naw, Sarigol, Shina Anda and Danhedjik) are settled in the district of Yakawland.

At the Province level, the Bamyan market makes the connection with the other districts and the Samaghan province.

At the national market level, the Kabul market corresponds to the business hub with Pakistan and the neighbouring countries.

The following map presents the local markets localisation in the district of Yakawland and the interviewed villages.

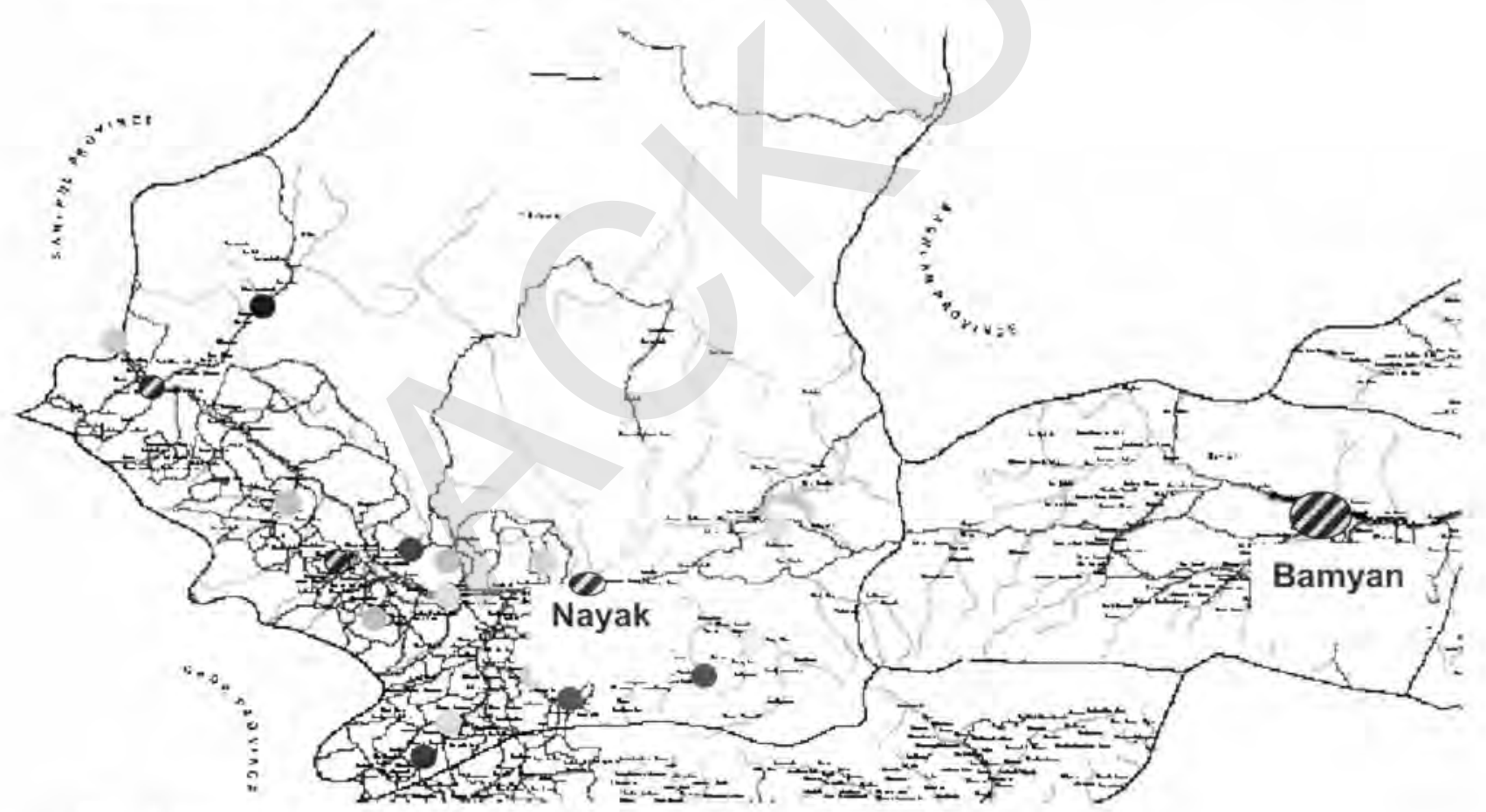

- 4 important local markets

4 local markets
6 villages of farmers

5 villages of breeders

Band e Amir cooperative 
Commercial exchanges study - Yakawlang district - April/May 2005

Solidarités

Figure 2: Localisation of the markets and the surveyed villages

16 


\section{a) The "small" local markets}

The 4 "small" local markets are settled in strategic places between mountains and sub valleys. These markets are composed of 10 to 30 shops in one block along the main road. These shop keepers are also farmers and breeders. Around $50 \%$ were opened during the visit. These shop keepers make the link between the connected villages and Kabul. They are around 5 in the district and 4 have been studied.

b) The local markets

- The Daga market: This market is composed of around 120 mud shops settled along the main road. One person is responsible for the market security. There are 3 bigger shops (electronic goods, plastic goods, handicraft, etc) and some shops are specialized in medicines, in mechanic purposes, reparation shop etc. 5 trucks belong to 5 shop keepers. The other shop keepers are farmers and/or stock breeders. They sell diversified goods with manufactured foods (biscuits, juice, oil, etc), plastic goods (shoes, tools etc) kitchen tools and food (rice, pea, bean, lentils, etc). A third of the shops are opened at the same time. The strategic place of this market makes the link between Daga region and Kabul and lesser with Nayak. The shop allowance reaches up to 6000 to 7200 afghani/year (120 to 144 us $\$$ year).

- Dares Chach market: 3 to 4 hours are necessary to reach this market. It is located in an enclosed valley and the traffic frequency turns around 1 truck/week. During the winter time, the traffic is usually off. The 60 mud shops ( 8 belong to refugees) are managed by the shop keepers who are farmers and stock breeders. Around a third were opened during the visit. Around 10 shops don't sell food and are specialized in reparation, medicines or no food goods. The shop keepers have to pay a rental amount of around 6000 afghani/year (120us\$/year). One guardian who pays 50 afghani/month (1us $\$ /$ month) is responsible of the shop security.

- Maruf market: this market is settled in half-way between Nayak and Daga market, on the middle of the shaman plain. During the floods, the road is more or less passable. This market is composed of around 65 mud shops only and several refugees are owners of them. There is no family home. 
c) The Nayak market

There are 480 shops but only 360 are in exercises. There are 4 categories of shops: the specialized shops (around 20) (reparation, spare parts, electricity, kitchen tools), the shops (around 10) which sell food in large quantity (sell by $50 \mathrm{~kg}$ bag of rice), the retailers (the most numerous) who sell goods by small quantity (sell by sere $=7 \mathrm{~kg}$ ), the shops (around 8) which provide only farm production means (fertilizers, pesticides, seeds). Around 30 shops in wood are settled at the end of the market. The majority of the shops provide diversified goods (some plastic shoes, soap, lamp, etc). Approximately one fifth of the shop is opened on a simultaneous basis.

$70 \%$ of the shop keepers are farmers and/or breeders. $30 \%$ of shop keepers are owners of their warehouse, the other rent their premises which belong to Nayak citizens (middle and rich people). The allowance amount varies according to the lighting site and the position inside the market (the shops built in the middle of the market are more expensive than the shop built in the extremity). The amounts are between 5000 afghani to 12000 afghani/year (100 to 240 us $\$ /$ year).

A mayor under the governor responsibility is supposed to manage the maintenance of the road and the canal which crosses the market, the security and the cleaning. The mayor has to check and fix the wheat flour price and the meat price. A collective meeting determines the convenient price of these goods on a monthly basis. According to the mayor, the local products are mainly sold to Kabul without any price control.

\section{d) The Bamyan market}

This market is located at the crossing road between Kabul, Bamyan district, Behsud district and Kahmard district.

Around 800 shops are settled along the road corresponding to the market. As above, there are specific shops (reparation, electronic etc handicraft, etc). A rice market is composed of around 10 tents. 10 to 15 traders shops (foods and inputs) are settled in the market centre whereas the retailers (staple foods, manufactured foods, vegetable, fruits) and some mobile retailers (fruits, vegetables) are made up the rest of the market. 
Commercial exchanges study - Yakawlang district - April/May 2005

Solidarités

e) The Kabul markets

All the main roads of Afghanistan are linked with Kabul and all the administrative services and private sectors are present in Kabul. Moreover, Kabul is close to an important city of Pakistan (Peshawar) and the commercial trades between these both cities are important.

19 


\subsubsection{The organisation and the links between markets}

Due to the enclosed mountainous area, the population used to live by selfgoverning. In the past and still now, the exchange in kinds was and is common in this circle. But this barter economy tends to be replaced by the money market.

Usually, some villages are connected with the local market and all these villagers sell and buy their goods there. A market is an autonomous strategic place making the link between Kabul and the villagers. So, there are usually few connections between the local markets.

Nayak market is not a central step to sell or to buy goods. It just corresponds to the biggest market of the district because of the higher population density (large cultivated plain) compared to the downstream (deep cultivate plain) yakawlang district.

However, some shop keepers come and buy inputs (fertilizers, seeds) to the Nayak market because of the low inputs availability in the enclosed markets like for instance in Daresh Chach, Daga, Sarigol Bazaar, etc. At the end, the shop keepers who are usually farmers and/or breeders avoid to depend on the other market. If a villager needs something which is not sold in the local market, he goes and buys it in an individual basis either in Nayak or in Bamyan markets.

The following draw illustrates the link between the local markets and the Kabul one.

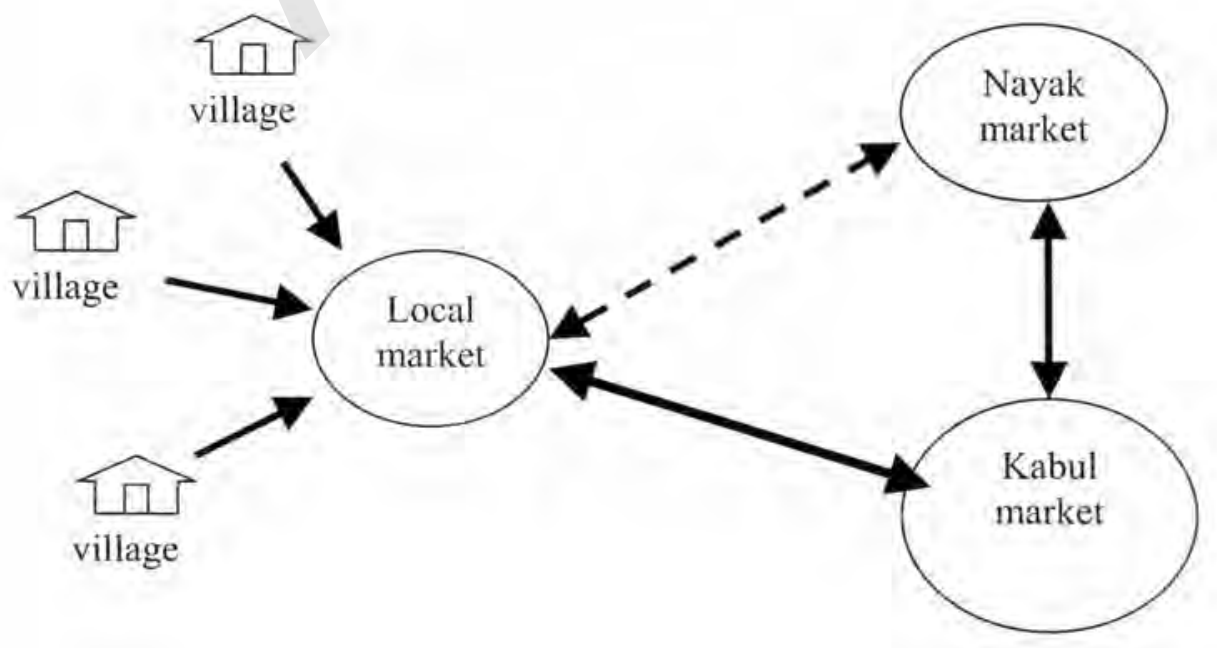


Figure 3: Perception of a spatial market organisation

At last, the Yakawlang is segmented according to the number of local markets.

\subsubsection{The stakeholders}

Along the commercial exchanges analysis, 4 stakeholders are directly implied in the commercial exchange. The other stakeholder is an important actor who allows the chain operations.

a) The direct stakeholders

- The producers: this category is composed of farmers (the big farmers with more than $3 \mathrm{ha}$, the middle farmers with between 1 and $3 \mathrm{ha}$, and the small farmers with less than 1 ha. $4 \%$ of the population are landless and practice share cropping) and breeders. Usually, the producers try to diversify their activity and so practice a mix farming. The production depends on their localisation and on the altitude. The following map presents the production according to agrosystem.

- The shop keepers and/or retailers: it is necessary to remind that the shop keepers are also producers. We can consider the shop keepers who sell mainly non food goods (plastics, tissues, soaps, some sweets, ete), the shop keepers who sell mainly staple foods (cereals, leguminous, sugar, etc) in small quantity (seer unit, $7 \mathrm{~kg}$ ) or in bigger quantity (by bags of 42 or $50 \mathrm{~kg}$ ). Given the standard size of the shop (less than $50 \mathrm{~m}^{2}$ ), the storage represents a maximum of 40 bags of cereals, pulses, dried fruits and unsold remaining potatoes. A shop is usually full of different goods which reduces the selling risk. The prices are regulated by the consumers thanks to the supply/demand marketing system.

The above following map illustrates the markets location.

- The transporters: At the local level, they are mainly settled in Nayak (more or less 90 trucks), Daga (10 transporters) and in Bamyan (unknown data). The owner of a truck employs a driver (around 3000 to $3500 \mathrm{afg} / \mathrm{month}$ in summer time). Usually, the local transporters of 
Commercial exchanges study - Yakawlang district - April/May 2005

Solidarités

Nayak do the traffic between Yakawlang and Kabul and few connections are recorded between Kayak and Bamyan.

- The traders: They are in Kabul or in other provinces. The Kabulis traders could be met given the trouble in Kabul during the mission. However, the commercial exchange officer of the project is in charge to meet and study them.

22 
b) The indirect stakeholder: the lenders. They have 2 functions and make loan for very poor people (middle and small farmers who represent a large population of the district) and for the shop keepers who want to increase their business. The lenders handle the local economy and practice the traditional banking system: when a shop keeper borrows some cash, the lender provides the demanding amount of cash. In return, the lender can take away shop keepers goods at low price up to the nominal amount. In every village, the shop keepers are in debt and usually, the farmers buy by credit the goods to the shop keepers. So, the financial system depends on the lender who can imply interests if the borrowers take time to bring back cash.

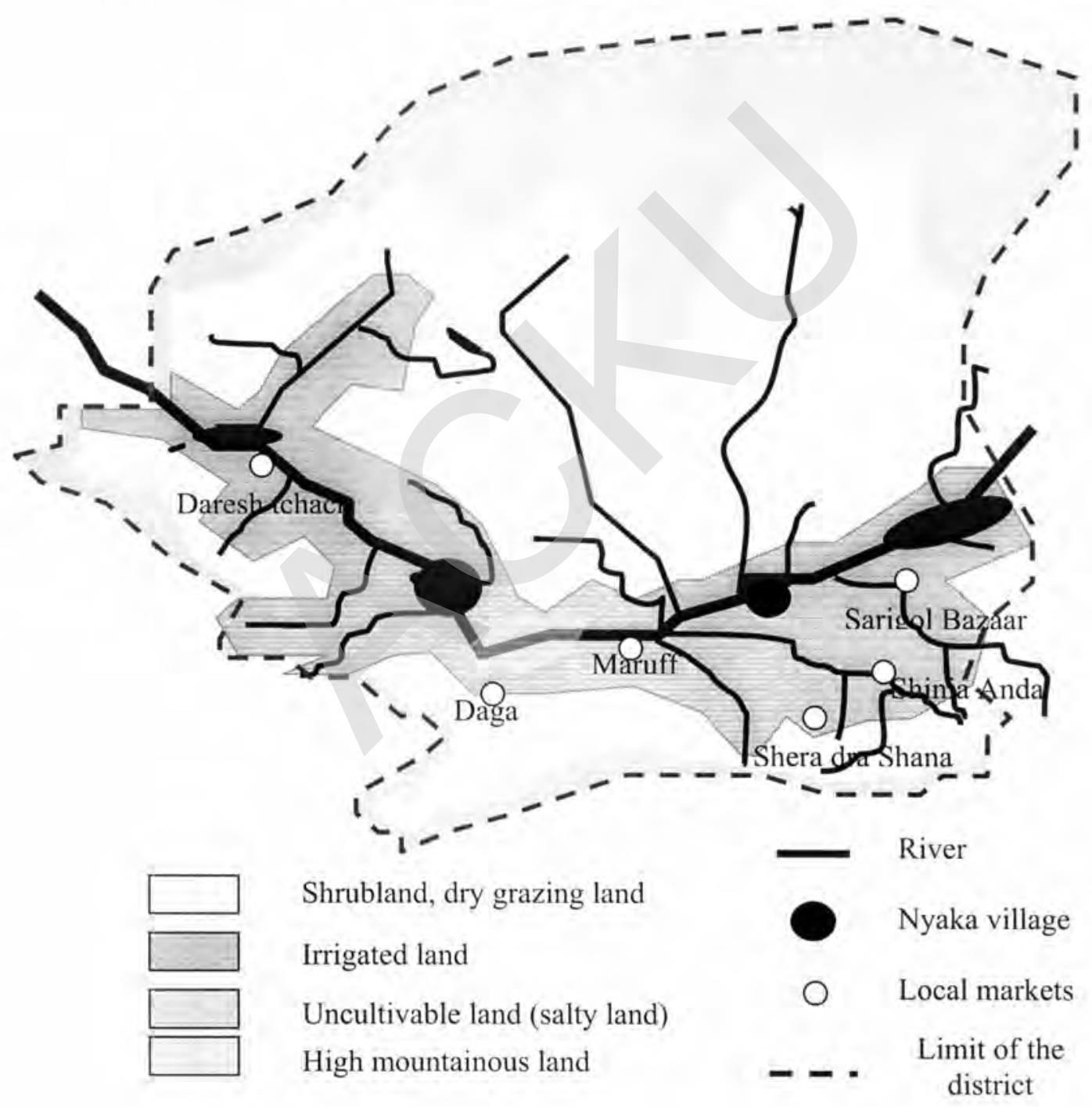


Commercial exchanges study - Yakawlang district - April/May 2005

Solidarités

Figure 4: Agro-ecologic map of Yakawlang and localisation of the markets

24 


\subsubsection{Relationships between the stakeholders}

a) The strategies according to the stakeholders activity

First, it is important to remind that $95 \%$ of the population depend directly on agriculture and rearing. Usually a standard family has around 0,3 ha of irrigated land, 0,4 ha of rainfed but only 0,2 ha are cultivated and breeds 2,3 sheep and 0,5 goats in average ${ }^{3}$.

- The farming activity

The individual strategies of the farmers are mainly to minimize the risk and to earn the vital cash for a year. By this way, the family produce wheat for self-consumption, cultivate potatoes as cash crop, sell his labour force and can migrate to cities for temporally works. In the case a lack of cash, the family may borrow money to the rich people or/and buy goods on credit from shop keepers. They usually pay back in kinds or in cash the high interests. The farmers who have enough cash try to plant fruit trees and poplar trees or capitalize on animals (goat, sheep, cow).

- The stock breeding activity

The livestock production represents a saving plan. Animals are important for milk, meat, wool, etc. and for vital cow-dung combustible production. Farming is still important because it provides foods and straw for animals. Either the breeders rear and sell animals head by head, or they sell number of animals in 1 time. The family with large herd needn't to borrow money and they can become lender. So for families, animal capitalization allow to get cash, to get combustible during the very cold winter (night under $\left.30^{\circ} \mathrm{C} ! ! !\right)$ and so animals represent a important resource.

- The shop keepers activity

First, the shop keepers are mainly farmer and/or breeder. They sell their products in an individual basis. The prices fluctuate between shops but usually are standardized thanks to the supply/demand system. To decrease the risk, they diversify their selling goods: all the shop keepers sell cereal, leguminous, cloth, domestic purposes, sweet, biscuits... but in small quantity. They usually don't sell new goods (foreigner or modern

\footnotetext{
${ }^{3}$ UNHCR, 2002. UNHCR Sub-Office Central Region - District profile, 18/09/2002: Bamyan province, Yakawlang disrict.

Solidarités, 2002. Food security assessment in afghan rural areas
} 
goods). At the end, the shop keepers sell the same goods at the same price but are more or less specialized in a specific kind of goods.

- The transporters

Usually, the owners of the truck are rich villagers of Nayak or Daga. They are big shop keepers or doctors etc... and they employ drivers. They always want to increase their business and force the producers and the shop keepers to sell the products or to go and buy products in saying the advantaged prices in Kabul (high local product price and low external products prices). During the low transportation activity in winter, the transporters can practices elsewhere.

- The traders

Due to the student demonstration in Kabul and the troubles in other cities during the survey, no traders were met.

- The retailers and the mobile retailers

For the same reasons as above, only few retailers were interviewed.

Retailers and mobile retailers are specialized. For instance, some retailers sell potatoes and onions, others sell only tomatoes, others only sell leaves and radish, etc. the perishable goods are sold in few quantity but the retailers propose various production (coriander, mint, other leaves, radish, beetroot etc...). They usually buy the daily or weekly quantity that they must sell. One more time, the retailers work in an individual basis. Given the few interviewed retailers, another survey is necessary to understand the links between the traders and the retailers.

b) Relationships between the stakeholders

- Producers/shop keepers relationships

First, in the visited markets, the shop keepers maintain that they are all farmers and/or breeders except in Nayak and Daga where respectively 100 and 3 shops keepers consider the farming as a minor activity. So we can consider that the shop keepers are mainly producers.

Due to the competition, the shop keepers are helpful and sell their goods on credit. According to some shop keepers, the commercial exchanges correspond mainly to familial or relative relationship. But the few information can not allow us to make any serious conclusion. 
- Producers/traders relationships and shop keepers/traders relationships The producers are in villages whereas the traders are in Kabul and they have few relationship. Some shop keepers go and sell or buy in Kabul and the shop keeper feel victimized due to the dominating relation of the traders. So the current brief business relations do not permit good relationships. However, the shop keepers who consider agriculture as secondary activity and who are owner of truck can get good contact with Kabulis traders. For instance, 1 shop keeper and owner of a truck in Daga buys goods on credit to a Kabulis traders and every year, they deal together for the inputs purchases.

- The lender/producers and the lender/shop keepers relationship

The lenders lend money to the poor villagers and to the shop keepers who want to increase their business. Anyway, the lenders want to apply interest in kinds or in goods. The lenders are usually respected rich villagers and look like "honest men" in front of the villagers.

\subsubsection{Economic chain running}

This chapter explains the commercial exchange establishment and the links between the stakeholders. First the commercial exchange analyses are explained then the fluctuation prices are reported thanks to graphs,

\subsubsection{The commercials exchanges according to goods}

The chains can be represented in 2 ways: the way of the staple food and the animals outputs chain and on the other way, the "cash crops" or living animals chain.

Here the staple food corresponds to the wheat (and barley) and the pulses; the animal outputs corresponding to the "krout" and the wool. The cash crop is the potatoes and the living animals sale correspond to sheep and goats.

The leather chain is different. As a matter of fact, a breeder sells a living animal to the butcher of the village. The butcher cuts up and sells the meat and the leather separately. A shop keeper buys and tans the fresh leather with salt. He repeats these activities before selling the leather to Kabul. 
The Yakawland district is usually not self-sufficient in cereal and in pulses and imports rice, wheat flour and some pulses (chickpea, red beans and lentil). But the crop production seems to increase thanks to the recent winter wheat introduction in Yakawlang. The surplus of pulses production (vetch, chickpea, "klol") is sold after harvesting or in spring winter. The surplus of "krout" is sold to Nayak and/or to Kabul markets in summer and autumn.

The following schema illustrates the most current chain. We must keep in mind that the shop keepers in Yakawlang district are also farmers and breeders. 
a) The staple food and the livestock outputs chains

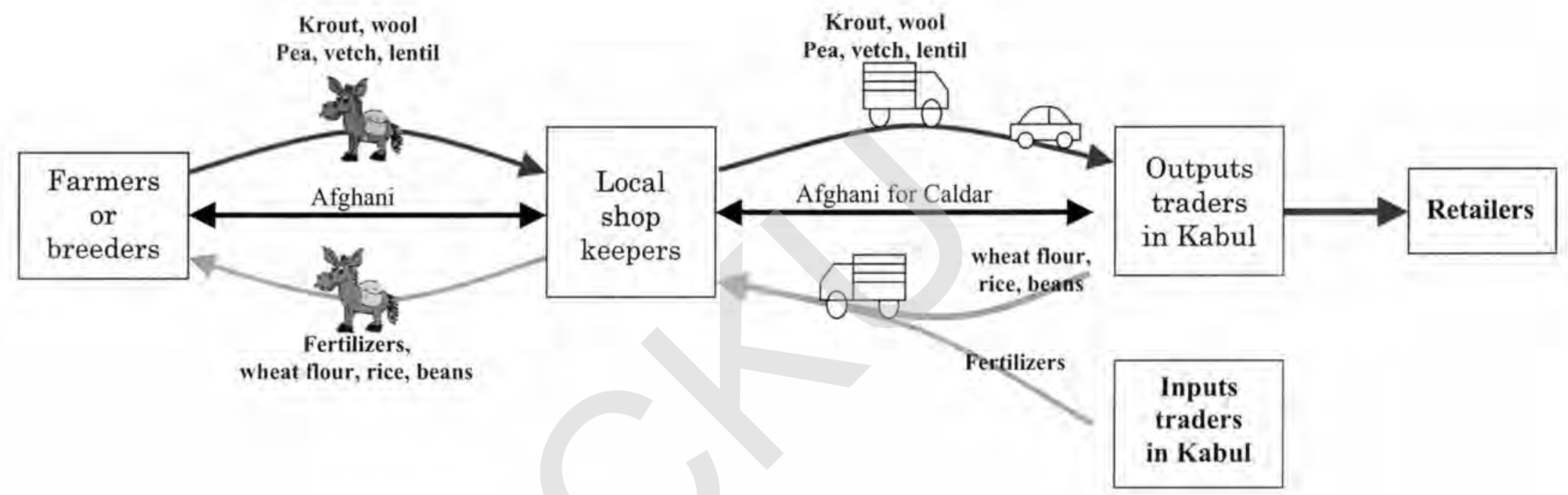

The farmers or the breeders go and sell their products to the shop keepers in the closest local market just after the harvest time. The supply being bigger than the demand, the farmers must sell a large part of their production to get as much money as possible. The shop keepers collect the maximum of goods during 1 or 2 months and, when ready, rent a truck on a collective basis ( 3 to 5 other shop keepers) to reduce the transportation costs. According to the season (the winter season corresponding to expensive transportation costs) and to the shop keepers localisation (Nayak market is closer than Dares Chach market for instance), the cost of the transport can reach up from 8 to 20 afghani/ $7 \mathrm{~kg}(+40 \%)$. When the trucks are full and after a trip of 1 or 2 days, the shop keepers go to Kabul and sell their goods on an individual basis. Sometimes in Kabul, they need to rent a pick up to dispatch the goods to the demanding traders. 
As the shop keepers need money as soon as possible and as much as possible to be able to buy quickly the fertilizers they need for the coming winter wheat cycle, the traders are in a dominating position.

Moreover, the currency being more interesting for them, the traders want to be paid in Caldar (the pakistanis currency). So the traders in Kabul buy the goods at low price (supply $<<$ demand) and speculate with the currency change. The shop keepers having few information and knowledge, the traders can fix their own and convenient currency rate exchange than the shop keepers can not refuse anyway.

At the end, the producers and the shop keepers are in a dominated position compared to the traders in Kabul who earn money thanks to the low buying price and the currency transaction. The transporters provide a costly service and they push the shop keepers to sell or buy in Kabul in saying the advantaged prices. 
b) The potato cash crop chains when the price is low:

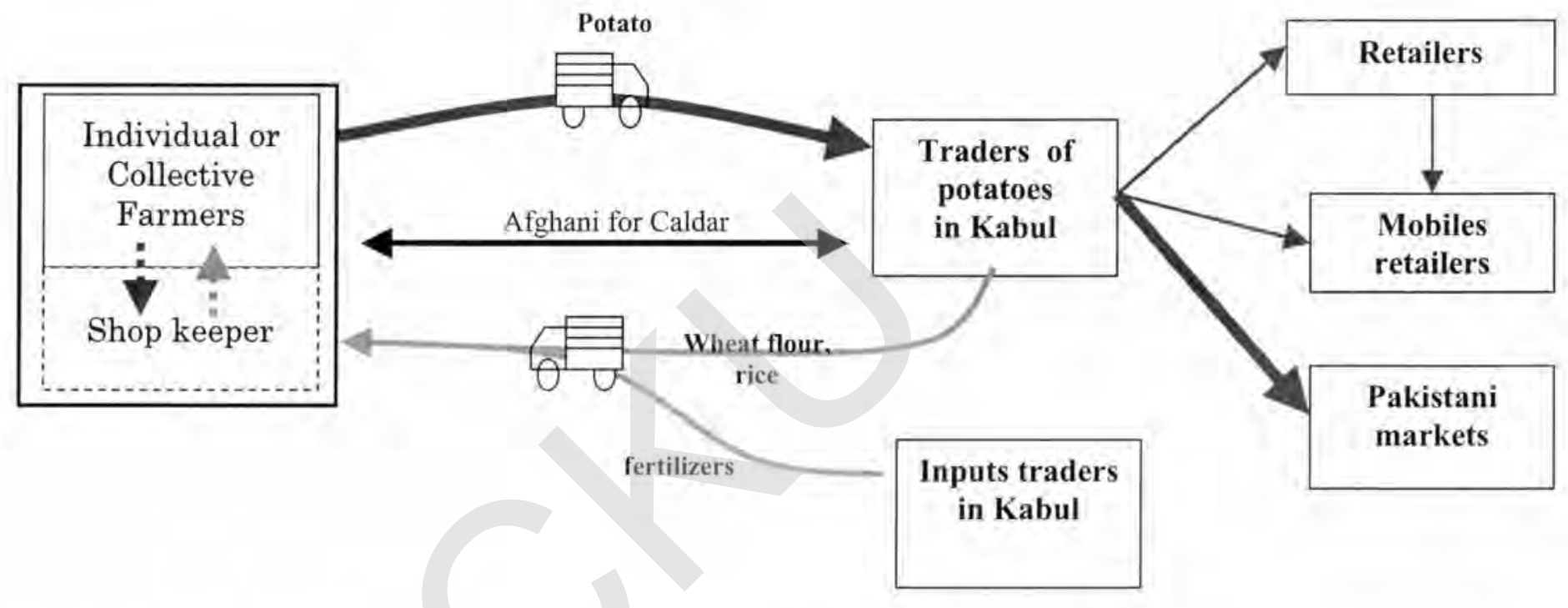

This chain can be observed just after the harvest and when the farmers need some cash. According to the production, one or several farmers (some shop keepers can also be in charge of the potato collection) go and sell to Kabul the potato production that they can not store. The cash incomes permit them to buy goods for the coming winter time (rice, wheat, sugar, oil etc. and fertilizers, seeds, and in a lower level chemicals products).

As above, the collective farmers or the shop keepers collect the maximum of goods and, when ready, rent a truck and go to Kabul on a collective basis. In Kabul, there are 2 specific markets for potatoes and the farmers or the shop keepers must sell to the highest bidder. Even so, the traders are still in a dominating position because of the high supply in autumn and the perishable potatoes (can rot). Moreover, the transporters want to make their business before the winter time and force the shop keepers to sell potatoes and to buy and bring goods for Yakawlang. That is why the farmers and the shop keepers sell potatoes at low price. 
c) The potato cash crop chains when the price increases:

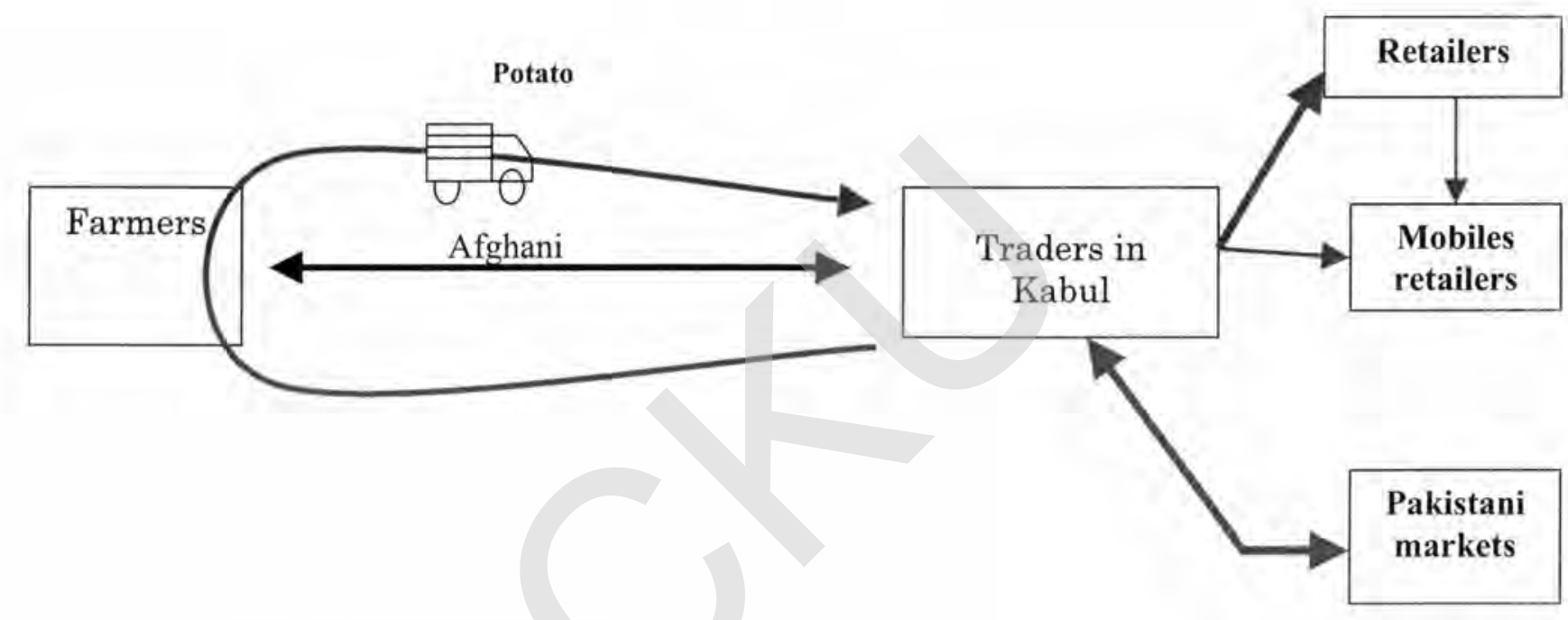

When the potato demand increases in Kabul and when more and more Pakistani traders order potatoes, the Kabuli's traders or the ones from Beshud province go and collect the potatoes in the villages. Because of the lack of information regarding the prices, the farmers sell their potatoes at a better price than above but do not know the loss of earning. If the potato price is attracted for the farmers, they can sell and reduce their production means, and next year, they will not have enough potato seeds to sow. 
d) The living animal chain

This chain can be observed when the breeders need cash, that is to say in autumn and at the beginning of spring. Usually, the goats or the sheep for sale are 6 months to 18 months old.

- First, the breeders can sell their animals in the local market head by head according to their cash demand.

- Second, a trader with truck comes and collects animals to sell in Kabul.

- Third, some united breeders can rent a truck and fill it to sell living animals in Kabul.

Usually, the price does not fluctuate too much but depends on the animal weight. As a matter of fact, in the studied market (Nayak, Bamyan), the meat price is controlled by a mayor. Some people also explained me that the meat price is also regulated in Kabul.

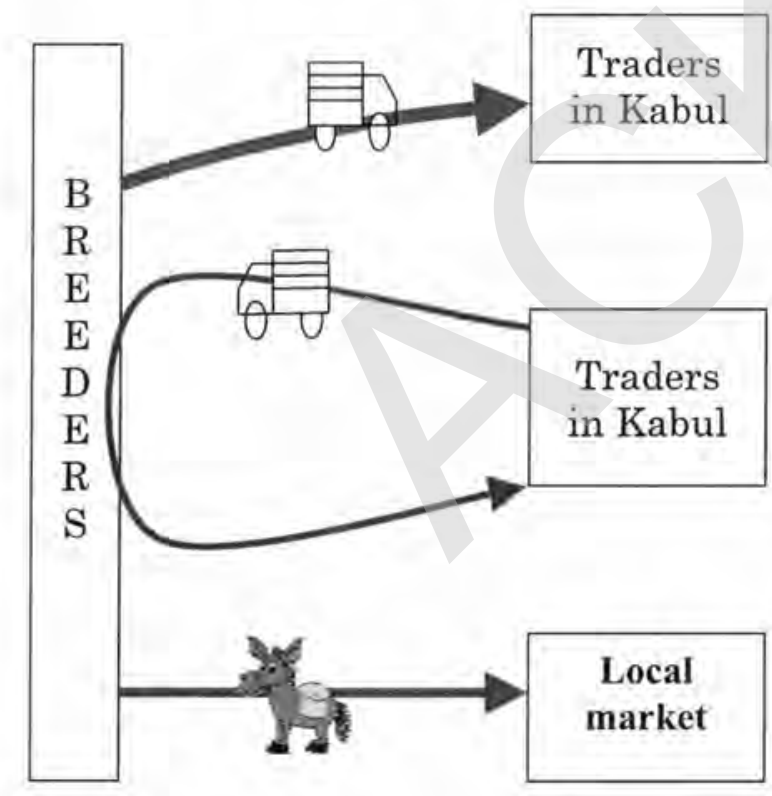


e) The winter chain: the inputs chain

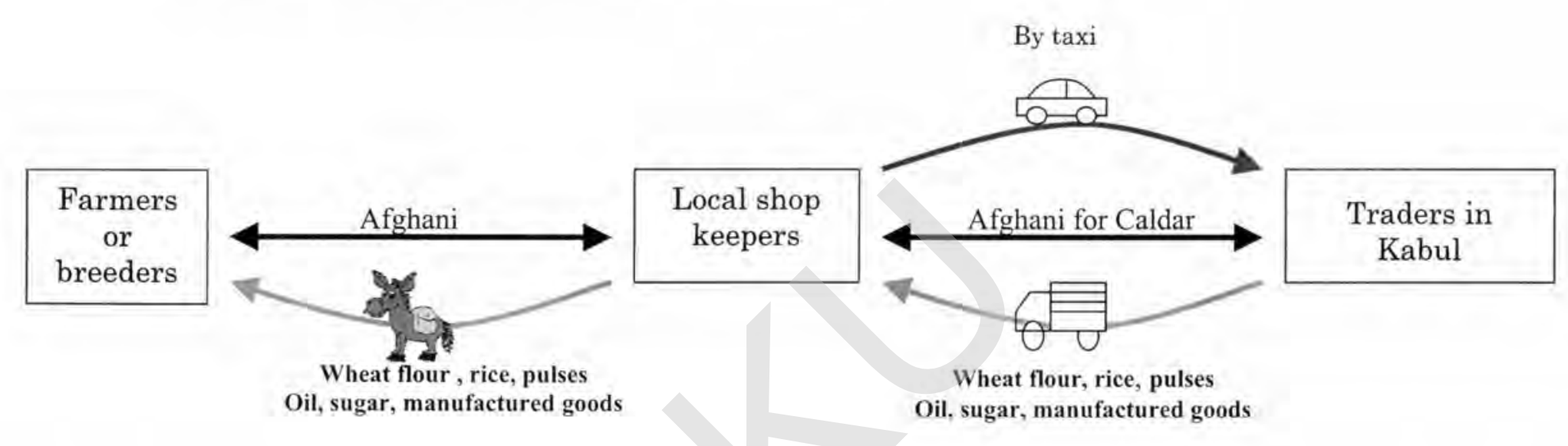

The winter sketch is different and not frequent given the road condition. It concerns the basic needs. Some shop keepers go to Kabul by taxi (600afg/trip, 12USD/trip) and buy some goods. Then they rent a truck with the other shop keepers and bring the goods back in their village. 


\subsubsection{The prices of the main exchanged goods}

Here, the prices are summarized in 1 graph, the first two show the price fluctuation of output products and the following two illustrate the price fluctuation of the inputs in the Bazaars of the valley (average data).

- The outputs fluctuation:

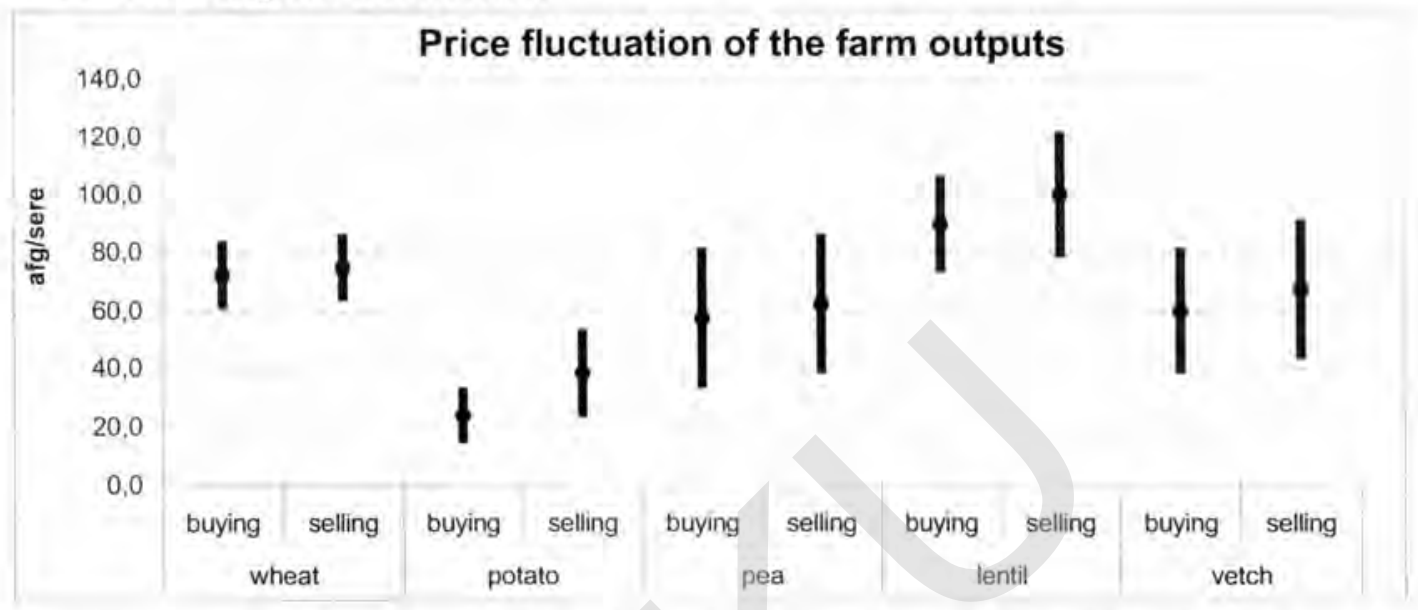

Figure 5: Price fluctuation of the farm products in the Nayak Bazaar

This graph shows that the potato price fluctuates more than the other goods. Given the different qualities, the low conservation and the seasonality phenomenon, the potatoes are usually bought at low price by the shop keepers and sold with better benefit. However, the largest potato production is sold to Kabul, and the remaining is sold in Nayak market.

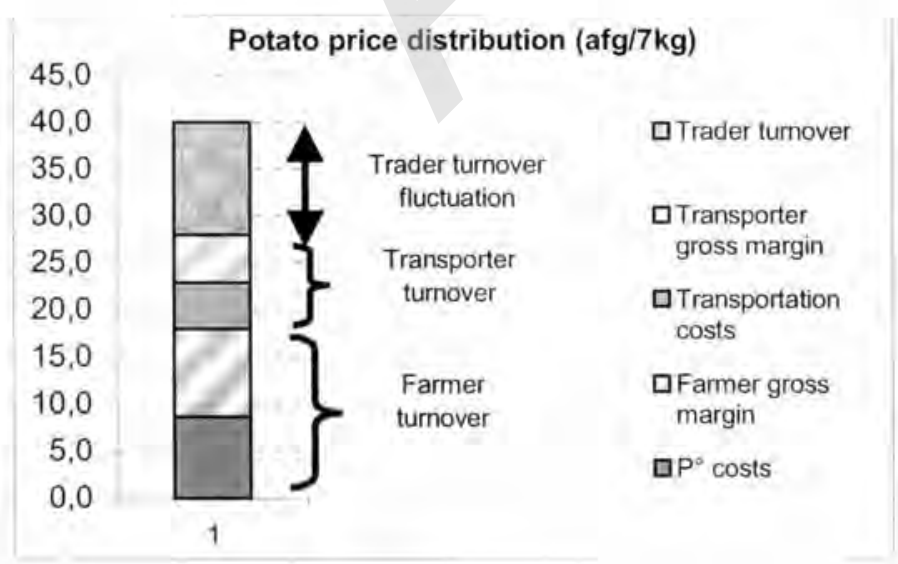

Figure 6: Local product gross margin made by farmers and shop keepers of Nayak Bazaar

This graph illustrates the distribution of the potato costs after the trip to be sold in Kabulis market. 
The turnover of the trader varies from $7 \mathrm{afg} / \mathrm{sere}$ to $22 \mathrm{afg} / \mathrm{sere}$. Some retailers explain that the Pakistani potato price can reach $120 \mathrm{afg} / \mathrm{sere}$, whereas the Afghanis potato can cost up to $60 \mathrm{ahg} / \mathrm{sere}(1 \mathrm{sere}=7 \mathrm{~kg})$.

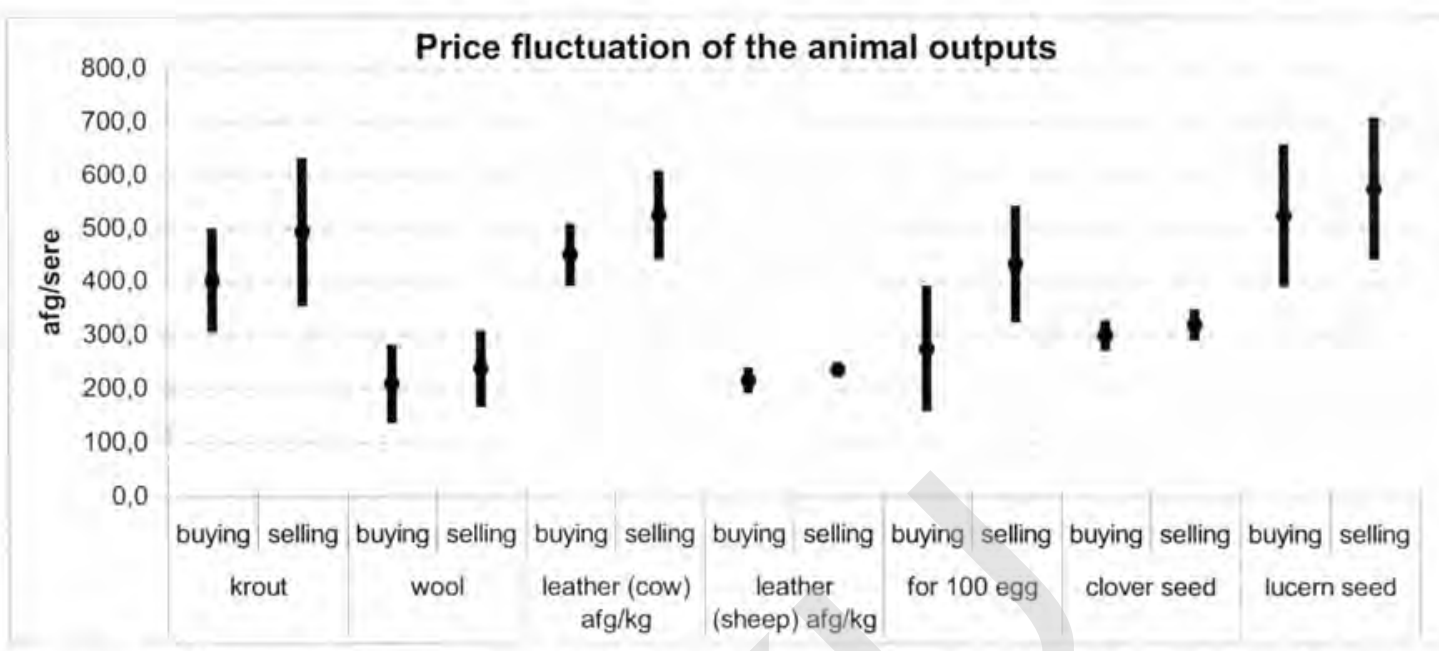

Figure 7: Price fluctuation of the livestock products and fodders in the Nayak Bazaar

This graph illustrates the high price fluctuation of the eggs and the krout. These products create the most benefit for the shop keepers even if eggs are more risky due to their non conservation during the summer. (The data for the eggs study come from 3 eggs producers interviewed and so are not significantly)

- The inputs fluctuation

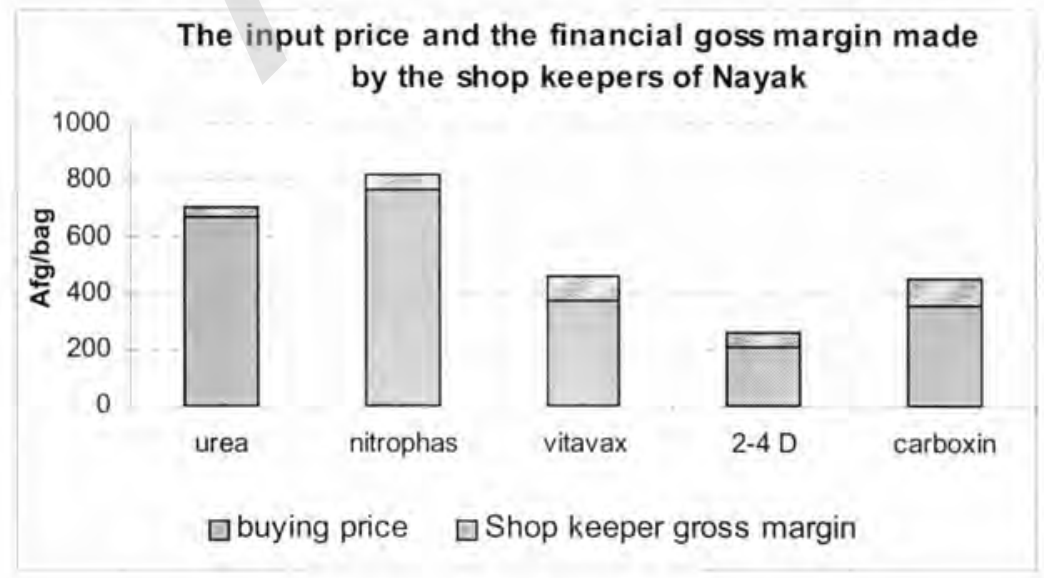


Figure 8: Input price and gross margins made by the shop keepers of Nayak Bazaar

This graph shows that the shop keepers don't make high profit and that for 3 reasons: First, the fertilizer prices correspond to a high amount for the farmers and if the price increase more, the farmers could not buy any bags. Second, farmers have few cash when they need to buy ; third, the farmers have doubt as to the fertilizer quality.

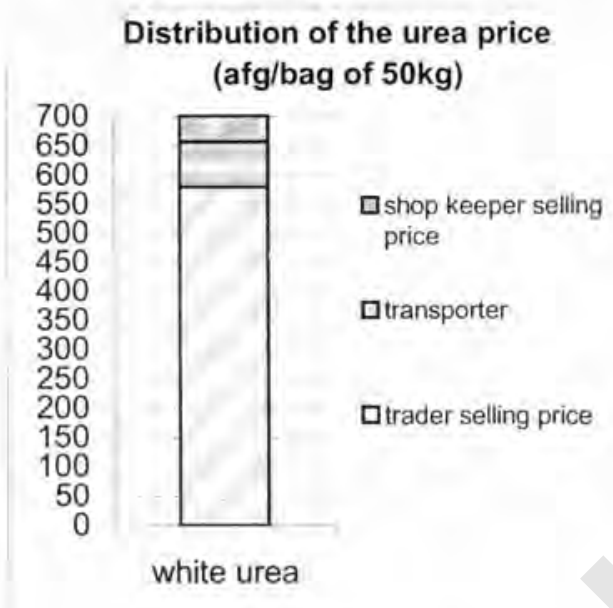

Here, the shop keepers make less than $7 \%$ of profit on urea (urea $46 \%$ of nitrogen, bag of $50 \mathrm{~kg}$ ). According to the selling inputs prices of the traders in Kabul, the transporters make most profit with around 50 to 80 afg/bag.

Figure 9: White urea price distribution

(data from the shop keepers of Nayak

Bazaar)

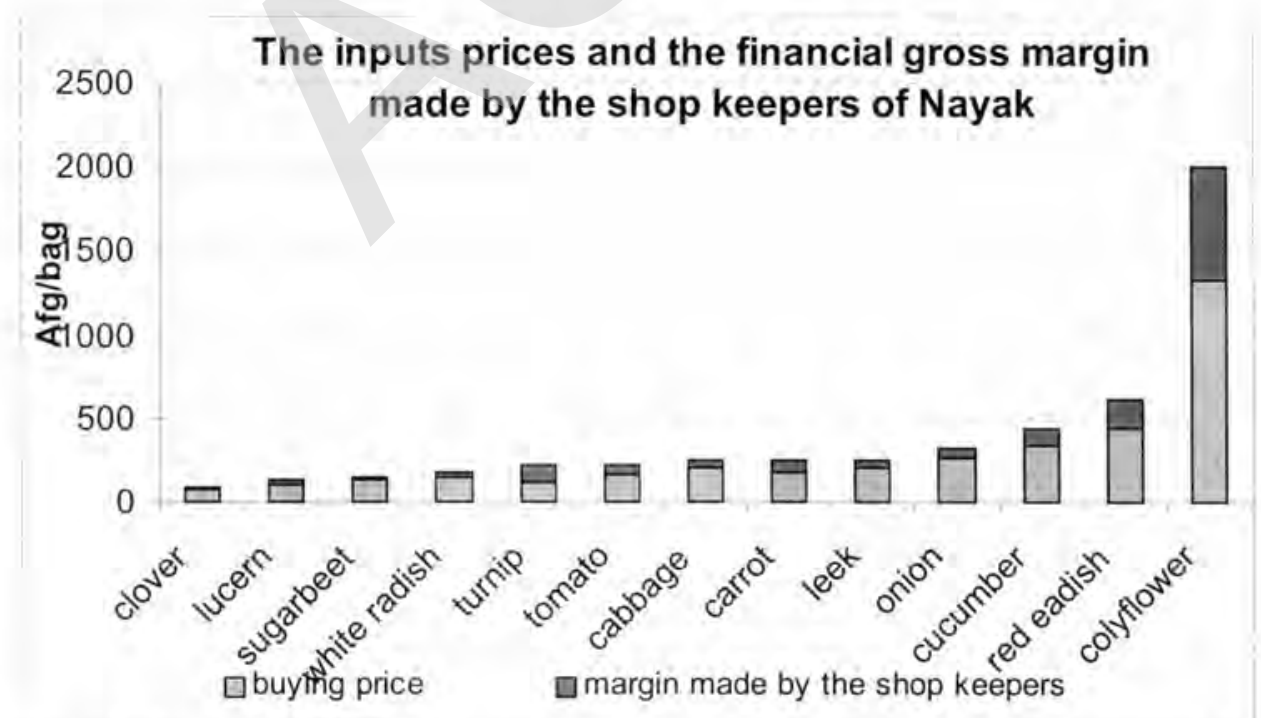

Figure 10: Seeds price and margin made by the shop keeper of Nayak Bazzar 
Even if the seeds purchase generates an interesting gross margin, few shops provide these inputs because of the difficulties to find good seeds in Kabul and also because the shop keepers are not sure to sell them on time and the farmers use not to cultivate vegetables. Nevertheless, some families have their own production for self -consumption.

So the marketing support of these inputs, implementing by gardening training will improve first the production, second the family diet and then the commercial exchanges (seeds and vegetables). In this way, the farmers and the shop keepers would benefit of this marketing support action. 


\subsection{The funding system of the commercial exchanges}

In Yakawland district, the families are usually considered as poor families with less than 0,5USD/person/day (annual GDP $=171 \mathrm{USD} /$ citizen). Due to the enclosed mountainous area, the very low winter activity and the farming production (wheat, potato, livestock), we conclude that the Yakawlang citizens have very low cash resources. All the more, few villagers hold the cash resource (chief of the village, important breeders, and entrepreneurs, doctors). So the farmers in tense situation and the shop keepers who want to increase their business depend on the loan of the rich people.

So the traditional lending system is mostly practiced and 3 loan systems were identified:

a) The farmer buys goods on credit to the shop keeper of the local market. As the prices fluctuate, the shop keepers fix a higher price than the real price at the sale period. The farmer pays back in an undetermined time. The interests are around 10 to $20 \%$ but it can reach up to $50 \%$ if the farmer takes to much time to reimburse.

b) The shop keepers ask money to a rich villager to increase his business. In compensation, the lender can take the foods he wants in the borrower shop. Usually, the dominating position of the lender lets him take the goods at low price which corresponds to the interest. These indirect interests fluctuate between 20 to $50 \%$.

c) The shop keeper can also borrow money to the traders in Kabul only if they have good relationship. In that case, the shop keeper must buy in credit the goods of the trader. Usually, the trader sells the goods at middle price and tries to make profit in the currency rate transaction. In fact the traders take an important tax during the currency rate because he usually doesn't know the afghani currency tendencies. It could explain the high transaction costs.

At the end, producers, shop keepers and rich villagers are closely linked on the cash resource basis. This traditional lending system with various interest according to the lender's mood can be a constraints for the borrower. Sometimes, the borrowers have problem to recover the money that small and middle shop keepers complained. So the close relationships weaken the economic situation of the small and middle shop keepers. 
Commercial exchanges study - Yakawlang district - April/May 2005

Solidarités

40 


\subsection{The information system}

For the price information:

Usually, the enclosed villagers have difficulties to get the current prices from Kabul, from Bamyan or from Nayak. The rare information comes from the relatives or the transporters who come back to the villages. They provide delayed information that it could mislead the shop keepers and the farmers. Of course, the closer to Nayak we are, the more relevant prices are. It is important to remind that the transporters want to make their business, so they encourage the shop keepers and the farmers to sell their goods because of the advantaged prices in Kabul, that is could be wrong.

\section{For the currency rate information:}

The richer shops keepers in Daga, in Nayak and in Bamyan listen to the radio (radio Kabul, BBC) to get the eurrency rate exchange (afghani/caldar). Some of them have satellite phone (thurya) and rent it $90 \mathrm{afg} /$ minute. These phones are usually used for familial purposes and not for commercial information purposes.

For all sort of information:

In Bamyan, a FM radio station provide interesting information for the citizens. Unfortunately, the radio program could not reach Nayak but with higher power transmitter, the communication could definitely increase.

\subsection{The main constraints}

During the survey and with the participatory technology development approach, 7 main constraints were identified at the local level. So after individual and collective meetings following by debates with the local communities, the villagers have to find solution by them selves. These are the main constraints for the farmers and, at a lower level, for the shop keepers. Unfortunately, the traders constraints could not be identified because of the student demonstration and the insecurity in Kabul. However, the Afghanistan marketing officer is in charge to meet the traders and to characterize what are the traders main constraints.

These mentioned constraints are probably not exhaustive but they avoid the local production growth and are a break in the commercial exchanges. These are: 


\subsubsection{The road and the transportation costs}

Due to the enclosed mountainous area of the yakawlang district and the bad road conditions during 6 months (October to may), the commercial traffics change according to the season. The transportation costs, calculated on the weight basis, oscillate from 8 or 10 afghani/sere ${ }^{4}$ to 16 or 18 afghani/sere for a Nayak/Kabul trip. The transportation cost after and over Nayak increases significantly because of the very bad road condition of the Shaman plain. The additional costs reach from 5 up to 8 afghani/sere whereas the distances are small.

The transportation cost analysis shows that for a trip Nayak/Kabul, the owner of a truck spends around $6 \mathrm{afg} / \mathrm{sere}$ (petrol, oil, driver, depreciation). The remaining money make his profit.

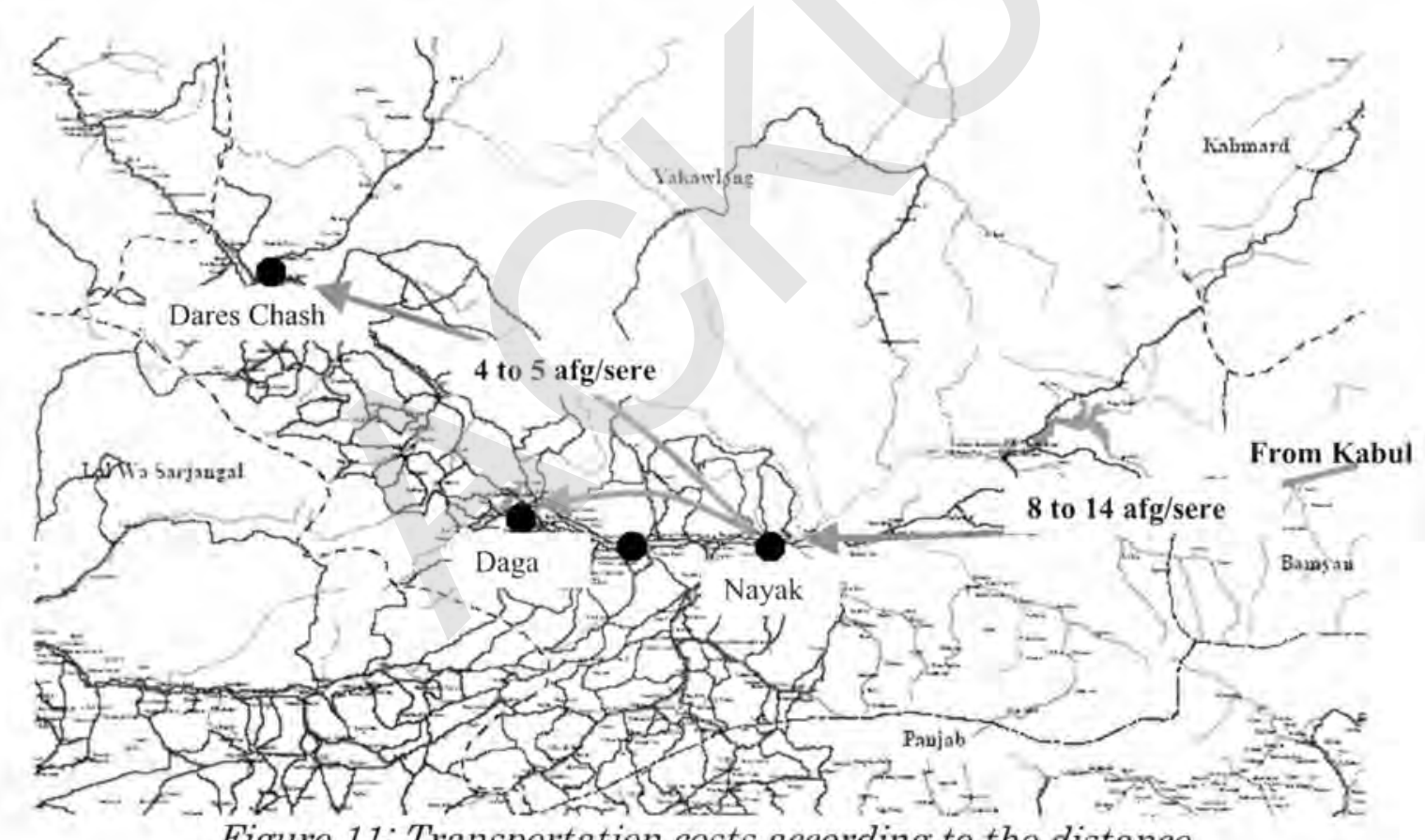

Figure 11: Transportation costs according to the distance

Because the farmers and the shop keepers are usually in debt and need some cash, they sell a large part of their production in harvest time and when the

\footnotetext{
${ }^{4} 1$ sere $=7 \mathrm{~kg}$
} 
transportation costs are low. At the end, because of the need of cash, the farmers sell their production when the economic environment is not in the favour of the producers and of the shop keepers.

\subsubsection{The currency rate exchange between afghani and Pakistani rupee}

The important commercial exchanges between Afghanistan and Pakistan generate transaction costs and the producers feel the effects. As a matter of fact, when Afghanistan sells its production, the Afghani is high compared to the Pakistani rupees during the autumn period. In opposite, when Afghanistan imports, the Pakistani rupee is strong. So the currency rate varies according to the commercial exchange potential and the season.

As the Kabuli traders want to be paid in Pakistani rupees, the shop keepers of Yakawlang either pay in Pakistani rupee if they have or they must pay the transaction currency rate cost. Usually the traders take advantage while the shop keepers don't know about the currency rate exchange. So there is a direct impact to the good prices that the shop keepers sell or buy.

Despites the research achieved in order to know the currency rate exchanges, I can not provide the official currency rate exchanges. The following graph illustrates the currency rate fluctuation during the year 2004 according to the shop keepers of Yakawlang district.

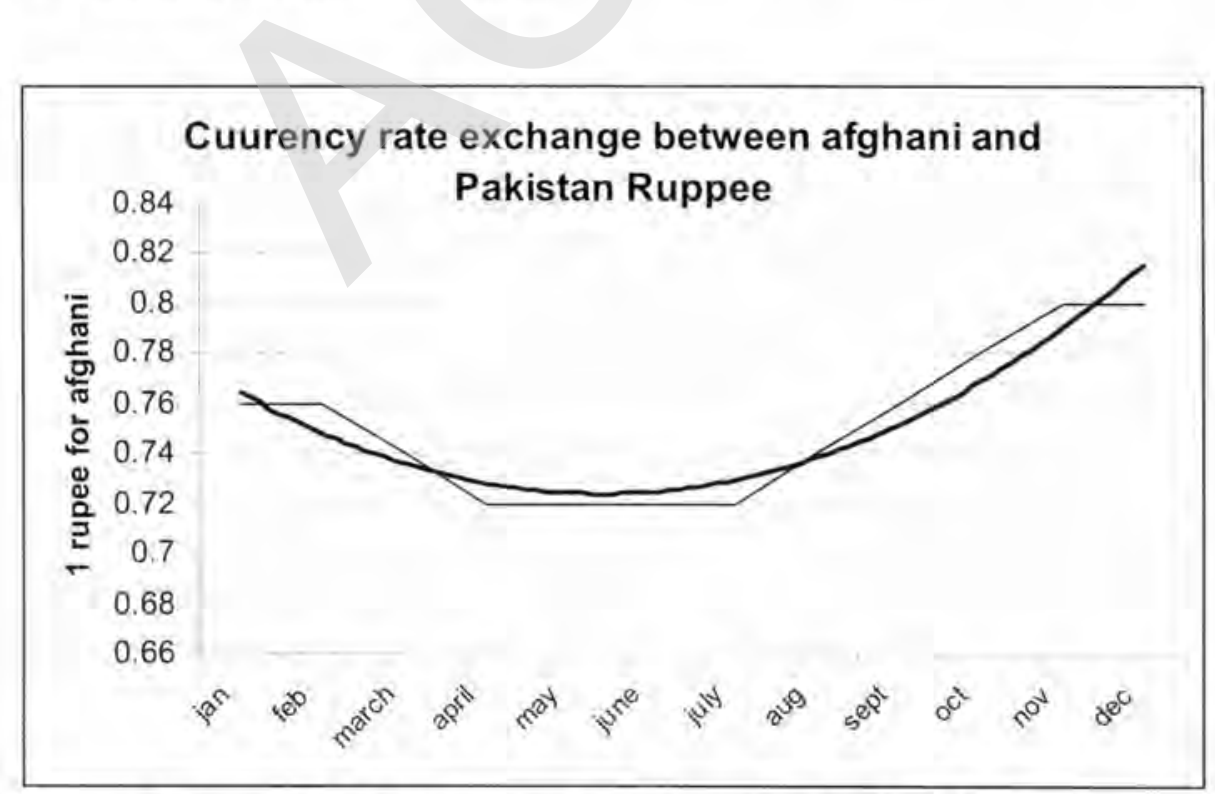

Figure 12: Currency rate fluctuation and cash needs 
At the end, the Kabuli traders, who use an anti-risk policy, buy at low price and speculate with the currency rate. These strategies have a direct impact to the local production sale.

\subsubsection{The inputs price fluctuation}

The price fluctuation depends on the currency rate exchange and the transportation costs which vary from season to season.

For instance, a bag of white urea is bough 580 afg in June and $600 \mathrm{afg}$ in April according to some shop keepers. It is sold around 700 to 730 afg in Nayak market. The transportation cost reaches from 70 up to 112 afg (10 to $16 \%$ of the selling price) according to the season. Usually the shop keeper earns around 5 to $7 \%$ on the buying price/bag.

This price fluctuation evolves 3 behaviour patterns:

- the farmers buy less fertilizers whereas the yields could increase thanks to fertilization plan.

- the farmer sells more potatoes to get more cash to buy fertilizers. Here the farmer is in a decapitalization phase of his production means. All the more that the potato seeds are very costly during the spring sowing time.

- The farmer makes a loan to buy fertilizers. He will pay back the loan with interest (between 20 to $50 \%$ ) when the potato will be sold.

So this input price fluctuation generates the impoverishment of the farmers and the high dependence regarding to the lenders.

\subsubsection{The seasonality phenomenon and the weak storage capacity}

Here we deal only with the potato production which is the cash crop producing high quantity while the yields reach 40 to 80 t/ha. all the more, the wheat production is self consumed and represents few or no traffic.

Given the 5 months of winter with low activities, the local production is naturally planned. The potato harvest time corresponds to the months of September and October and tons and tons saturate the market. As the matter 
of fact, the very low storage capacity forces the farmers to sell the large part of the production at low price, all the more that they need cash to buy inputs for the following cropping season (winter wheat) and the familial basic needs. Furthermore, an investigation realized by the project manager shows that 18 to $20 \%$ of the potato production can be loosen during the storage.

The traders sometimes export the potatoes surpluses to Pakistani markets, whereas they import potatoes from Pakistan when the local potatoes stock decrease, that is during the spring.

The fact that the farmers need cash and that the price is low, it obliges the farmers to sell more potatoes and so to store less seeds for the next cropping year. From here, the farmers have the choice either to buy less fertilizers, basic needs etc., and/or to make a loan. This decapitalization could have a huge impact at the local level.

So this seasonality phenomenon generate inter dependences between the producers and the lenders. It also has impact to all the stakeholders while the transporters make profit thanks to the potato production. What will be the impact at the Yakawlang district level if the purchasing power of the farmers ( $90 \%$ of the population) decrease?

\subsubsection{The lack of cash and the farmer debt burden}

The farmers have few saving cash because of the low selling price of the potato and the high input prices. To satisfy the cash need, the farmers might buy goods on credit from the shop keepers or make loan to a lender. The farmer difficulties to bring back this money have a huge impact on the shop keeper business who may make a loan at his turn.

So the lack of cash to the farmers generates impacts to all the economic chain. All the more, the interest rate can reach $50 \%$, but turn around $20 \%$. The approximately $60 \%$ interviewed farmers are in debt and have to reduce their input costs and the domestic purchases to decrease the following debt.

At the end, the lack of cash:

- makes the farmers under the lender domination,

- can disturb the business of the shop keepers who may be in debt, 
- reduces the farm input purchases, producing lower yield so less cash. It generate a decreasing domestic purchasing power of the farmers $(95 \%$ of the population depend on the agriculture $)^{5}$

\subsubsection{The lack of information with Kabul market}

Due to the enclosed valley of Yakawlang, there is no phone connection except the thurya satellite phone. The transporters and the taxi men provide information from Kabul but these data can be wrong.

So, a small part of the population have access to market information. The majority of the producers and the shop keepers don't know market tendencies and sell their products when the commercial exchanges are not in their favour. After a collective meeting, the producers and the shop keepers complain about the lack of price information. However some of them would like to speculate according to the price fluctuation.

${ }^{5}$ UNHCR Sub-Office Central Region - District profile, 18/09/2002: Bamayan province-Yakawlang district 


\subsubsection{The lack of knowledge where to sell and buy in Kabul}

When the shop keepers arrive in Kabul, they go and meet traders in the 2 markets of potato. Usually, they sell from door to door until the trader condescended to buy potatoes. And it takes time since the potatoes market is satured.

This lack of knowledge about the traders has 2 main impacts to the shop keepers and so to the farmers:

- First, the more time the shop keepers spend to sell in Kabul, the more the products' quality decreases and rotten potatoes can damage the production.

- Secondly, the inputs prices increase with the staring winter wheat sowing season starts and the shop keepers are in charge to provide fertilizers for the yakawlang farmers. So the shop keepers sell quickly potatoes and so at low price. The shop keepers with less benefit buy less inputs. At this same time, the transportation costs increase and so the fertilizers price increases for the yakawlang farmers. So the farmers buy less fertilizers etc.

It is important to mention that the shop keepers sometimes don't know where to buy good fertilizers. According to the IFDC representative in Kabul, there are around 2000 wholesalers who provide inputs, but the quality lets the shop keepers suspicious because of the farmers complains.

At the end, the lack of knowledge of the market when the shop keepers arrive in Kabul generate a loss of earning.

The following frame presents the some constraints according to the stakeholders. The stars give idea about the importance level.

\begin{tabular}{|l|c|c|c|c|}
\hline $\begin{array}{l}\text { Difficulties to find inputs: } \\
\text { price/quality/availability }\end{array}$ & $\begin{array}{c}\text { Producers } \\
\mathrm{XXX}\end{array}$ & $\begin{array}{c}\text { Shop keepers } \\
\mathrm{XXX}\end{array}$ & Transporters & Retailers \\
\hline Fluctuation of the input prices & $\mathrm{XXX}$ & $\mathrm{XXX}$ & & \\
\hline Low potatoes selling price & $\mathrm{XXX}$ & $\mathrm{XXX}$ & & \\
\hline In debt and lack of cash & $\mathrm{XXX}$ & $\mathrm{XX}$ & & $\mathrm{X}$ \\
\hline $\begin{array}{l}\text { lack of information about the } \\
\text { market in Kabul (price, place }\end{array}$ & $\mathrm{XX}$ & $\mathrm{XXX}$ & & \\
\hline $\begin{array}{l}\text { Lack of communication inside } \\
\text { the valley }\end{array}$ & $\mathrm{X}$ & $\mathrm{XX}$ & & \\
\hline Fluctuation of the currency rate & $\mathrm{X}$ & $\mathrm{XX}$ & & $\mathrm{X}$ \\
\hline Unpaid debt by the farmers & & $\mathrm{XX}$ & & \\
\hline
\end{tabular}


Commercial exchanges study - Yakawlang district - April/May 2005

Solidarités

\begin{tabular}{|l|l|l|l|l|}
\hline $\begin{array}{l}\text { Will to develop their activity for } \\
\text { selling in Kabul }\end{array}$ & $\mathrm{XXX}$ & $\mathrm{XXX}$ & $\mathrm{XXX}$ & $\mathrm{XXX}$ \\
\hline High transportation costs & $\mathrm{XXX}$ & $\mathrm{XXX}$ & & \\
\hline
\end{tabular}

48 


\section{Conclusion}

Yakawlang district is located in an enclosed mountainous area where the severe winter stops the farm activity during 5 to 6 months. The population is mainly composed of Hazara people who practice a poly-cropping/breeding system. This population is directly linked with the agricultural sector as the shop keepers are also producers. The farmers produce staple food for self-consumption (wheat, barley, pulses) and potatoes as cash crop. The fruit and the vegetables productions are still low and are self-consumed. Sheep, goat produce milk for the "krout" : it is a sort of cheese, very appreciated by the Kabulis, but which also corresponds to a saving bank.

The high seasonality phenomenon induces a very low selling price of potato for the farmers in September and in October. All the more, the weak storage capacity of the farmers obliges the producers to sell their own production as they need some cash to buy inputs with increasing price for the coming winter wheat season. This economy disadvantages force the producers and the shop keepers to borrow money from rich villagers. This interdependence weakens the business development given the high interest, the increasing input price and the low selling potato price.

The low information and communication means do not permit the farmers to negotiate when they want to sell outputs (mainly potatoes, surpluses of pulses and krout). This situation keeps them under the Kabulis traders and transporters' domination.

\section{Proposal and recommendations}

Given the fact that:

- the high transportation costs,

- the annual currency rate exchange,

- the high fluctuation price of the inputs,

- the seasonality phenomenon and the low storage capacity of the farmers generating satured market and low potato price,

- the lack of cash and the farmer debt burden,

- the lack of information transparency between Kabul market and Yakawlang district,

I propose 5 suggestions to respond to the $4^{\text {th }}$ last constraints, the 2 first constraints concerning the public property. 
(1)- To regulate the seasonality phenomenon and to increase the storage capacity, some individual and/or collective potato storage could be built.

(2)- To fight again the input prices fluctuation and to reduce the production costs of the farmers, one-stop buying when the input prices are low. According to an order, cash advanced and collected points could be placed to the producers.

(3)- To avoid high interest and inputs purchases when the prices are high (usually when farmers need and get cash), a proximity loan system for the producers.

(4)- To improve the information transparency and to facilitate the shop keepers arrivals in Kabul, a marketing information services could be developed in order to provide market tendencies and traders contacts.

(5)- to create customers loyalty, agreement between farmers and traders could be settled in order to respond to the consumers demand.

\subsection{Individual and/or collective potato storage}

Objective: To increase the potato storage capacity of the farmers and to improve the storage techniques.

Given the individual behaviour trends of the Afghanistan people, the individual storage unit or collective storage unit for 3 to 5 farmers are better adapted. Storage building and storage techniques, coming with training, will permit to increase the storage capacity, to improve the conservation and to reduce the potato loss during the storage period. At the end, the storage capacity improvement will generate more potato sale and so better farm incomes.

For the storage unit settlement, some steps are recommended:

- To select some strategic villages for a snowballing effect.

- To select some farmers who agree to deal with the storage capacity improvement project. They must have a good relationship with the villagers. It is essential to select neither the richer nor the poorer to facilitate contact. The selected farmers must be open minded for the innovation development.

- To assess the storage capacity per each selected farmers or group of farmers.

- To provide a technical support for the depot building (to avoid metallic structure and to develop the local material). 
- To train in the storage management (potato sort out, to clean hessian bags every year, to avoid temperature differential, ventilation and moisture management etc...).

- To register the quantity, the quality of the stored potatoes for each selected farmers or group.

\section{Advantages and disadvantages:}

The storage unit building needs few cash investment and few labour force. The storage needn't specific costly chemical products given the harsh winter. However, the temperature mustn't decrease under $4^{\circ} \mathrm{C}$. It can be easily apply and extend to local families. The time for the rigorous storage, the surface to build storage unit and the storage temperature management constitute the main drawbacks.

\section{Impact of the storage units:}

First, the farmers will have less potato loss, better potato quality and so more potatoes to sell and to sow for the next cropping year. Given the high price of the potato seeds during the sowing time, the farmers who needn't to buy potato seeds because of the storage improvement would spend $2600 \mathrm{afg} / \mathrm{djerib}$ that is $50 \%$ less (5300 afg/djerib) than the farmers who must buy potato seeds (see Appendix 3: Production costs of pulses and potato productions). So the storage capacity improvement will increase the purchasing power of the potato producers.

Second, it will permit to store and to provide potatoes when the market is favourable. Third, the farmers will have more cash, which will increase the familial condition and the production mean purchases (more fertilizers, more and better seeds etc.).

\subsection{Collective purchases and collective point depot}

Objective: To improve the inputs availability. To develop collective purchases when the market is favourable in order to decrease the production costs of the farmers. To show the collective purchases process and its benefits.

Due to the annual inputs price fluctuation, the low input availability in the Yakawlang district, the empty existing depot in Nayak and the low cash availability when the inputs price are low, the farmers could be supported to buy inputs when the market price is favourable. Thanks to a local organisation, the farmers of a village could order and purchase inputs in a collective basis (collective purchases) according to specific conditions (see below). After the purchases, the input bags are unloaded in the collect points corresponding to the depot. The local organisation would inform the farmers to come and pick up their ordered inputs bags knowing the depot conditions. 


\section{Specific conditions:}

- Payment condition: the farmers make down payment to show their undertaking. The payment condition must be clear before ordering and purchasing the goods. The reimbursement problems are under the community responsibility for a better payment recovery. In fact, Solidaritiés could deal with the community, the community being in charge to collect money from farmers. The payment must include the input price, the transport costs and the storage costs. During the first order, the storage costs must be low.

- Depot condition: the depot is not a storage place. The goods must be taken away when arrived. The depot consists in having a collect point to facilitate the goods distribution. This would avoid conflicts about damaged inputs during a long term storage.

- Order condition: the order quantity per family must be fixed before the deal with the farmers in order to avoid business. The objective is to decrease the production means cost and to provide inputs at lower price for poor farmers without making profit with business development. However, some shop keepers can be included in the process to show the benefit of the order organization.

For the collective purchases and depot equipping, some steps are recommended:

- to visit villages and to meet the community to present the existing depot and the collective purchase project (objectives, payment conditions, depot conditions, order conditions etc).

- to select the people who agree to order inputs. To heighten the community responsibility about the payment condition and the rules of the project.

- To order according to the villagers' demand. To inform that the local organisation team will present the quotations and will collect a part of the money two weeks later. The down payment amount must be discussed before.

- To make quotations (price, quantity, quality, with or without loadingunloading price, delivery date etc) at different levels: transport quotation, shop keepers quotation, traders quotation, in Nayak, in Bamyan, and in Kabul.

- To go back and visit the villages and present the quotations to the villagers and the community. To confirm, to change or to cancel the order according to the community decision.

- To collect the money in checking the order list. To remind the payment conditions and the rules of the project.

- To deal with the traders, transporters and/or other stakeholders regarding the order. To purchase according to the order. A proximity loan system could make the cash advance for 1 to 3 months.

- When the goods arrive safely, to store in the depot. To write on the bags what belong to whom and this, village per village. 
- To train the people who will be responsible of the storage, (store management training with Solidarités team).

- To go and visit the villages to inform that the farmer must go and pick up their inputs according to the previous conditions,

- If farmers are satisfied, to follow the order process.

- If the farmers are not satisfied, to identify where the constraints are.

\section{Advantages and disadvantages:}

First, inputs will be available according to the farmer's demands. Second, the fertilizers costs will decrease from 5 to $15 \%$ regarding the annual price fluctuation. Third, the shop keepers, who are also farmers, could be more introduced in the process to increase their business. Forth, the storage operating costs will be low given the short storage time. Fifth, more inputs price transparency. Sixth, a delay payment system easier to manage for the household budget. Seventh, the household could better plan their budget, knowing the quantity they ordered. Eighth, the transporters business will be improved given the higher demand of inputs in case of success.

Due to the low cash availability of the farmers, these collective purchases will perfectly work if there is a proximity loan system to make the cash advance. If the farmers are really interested by a collective purchase, they will borrow some money from the rich people who could make their business, that will disturb the rural development process. So, proximity loan system is recommended.

\section{Impact of the collective purchases:}

First, knowing a fertilization purchase plan, the fertilization plan will generate a better production, so more cash for the farmers if they produce cash crop as potatoes. Second, the price transparency will decrease the unfair competition. Third, this organized system could snowball for others goods purchases (seeds, tools, medicines). Forth, the collective purchases could create customer/traders loyalty and agreements could raise.

\subsection{Proximity loan system}

Objectives: to provide the district with a financial service for the farmers in order to support their lack of cash availability which is a break in the Yakawlang district development.

Knowing the numerous indebted farmers and the various interests, the low cash availability when the market is in favour with the farmers and the possibility to increase the loss of earning by playing with the annual price fluctuation, a loan system settlement will help the farmers to lessen their dependences facing the lenders and to increase their purchase power. This loan system access will allow the farmers to buy inputs and or to delay the cash crop sale when the market is favourable. 
For the proximity loan system. some steps are recommended:

Firth, the micro finance project setting up must be well studied before any interventions. Usually, this kind of project must be realized by experimented organism (NGO, consultancy office, private enterprise) who also knows the local population behaviour. The first steps are:

- To study the population about the perception of the loan system and the interest.

- To select the targeted population according to specific criteria and the project objective: selection according to specific activity, to poverty level, to geographic situation, to collective or individual activity etc.

- To assess the targeted population solvency. For that, to identify the reason of the credit demand. To build with the beneficiary(ies) an individual and/or collective project. To fix monitoring indicator to evaluate the project process.

- To fix rules and conditions of the loaning: to follow the project objective, borrowed volume, payment delay, rate interests, the penalties etc.

- To calculate the demand financial volume which would place at the beneficiaries disposal.

- To monitor the farmer loan according to the beneficiary(ies) project. To regularly assess the farmer project with above indicators.

\section{Advantages and disadvantages:}

First, the proximity loan system will let the stakeholders less interdependent. So the shop keepers business will not be troubled by the unsure farmers reimbursement. Second, the farmers will buy more inputs, so the production (cash crop or staple food) will increase, and the household conditions will be improved too. Third, the family condition improvement will generate more traffic, so more business for the shop keepers and the transporters,

The main danger is the non-payment of the loan. As a matter of fact, a lot of farmers are used to deal with NGO and think that NGO are only donors. Some farmers will not pay back the loan considering the help as a due, that is why the community must be taken in hostage for the reimbursement.

Impact of the proximity loan system:

Because of the individual behaviour of the Afghanistan people, and the opposition to progress because of the low cash availability, the loan system will develop individual project and specially farm project while farmers are around $90 \%$. Thanks to the potato price speculation, the farmers will earn more money while working as before and could invest wherever.

\subsection{Marketing information services (M.I.S.)}


Objectives: to inform the farmers and the shop keepers about the market prices in Kabul. To provide room for negotiation to the farmers and the shop keepers. To propose traders contact to the farmers and the shop keepers.

Due to the lack of information about the market prices, the low negotiation power of the farmer in front of the dominating traders and the loss of earning because of the lack of farmers knowledge, a M.I.S. will help the farmers and the shop keepers to know when to sell and where to sell and/or buy. "Availability of information about seasonal price movements should, in time, facilitate decisions about when to sell the crop and also mean that the urban consumers will not be faced with alternating gluts and shortage ${ }^{206}$. "Market information can be used by those involved in the marketing process to make better marketing decisions"7.

\section{Some recommendations for the Market Information System:}

- "The MIS access must be totally democratised. The information should be easily accessible to the users in terms of the convenience in obtaining it, and the information should be free or relatively inexpensive.

- The information should be relevant to the needs of users, i.e. the information must be what is required by the users. So MIS is mainly interesting for the farmers who produce crop for sale (that is potato, pulses and krout) and who needs inputs (fertilizers, pesticides, herbicides).

- The information should be meaningful, i.e, the information must be precisely specified. There should be no ambiguity in terms of the market and specific commodity and variety for which information is provided.

- The information should be understandable, i.e. it must be in a form which can be interpreted quickly and easily.

- The information should be reliable and impartial, i.e. it must be accurately and regularly collected and disseminated, and there must be no question of bias involved in the collection or reporting of the data.

- The information should be promptly available and timely, i.e. once collected it must be quickly disseminated"2.

- Several information tools to communicate market information to the farmers, the shop keepers and the traders must be identified and known by the users. For instance, the radio, the local newspaper, the editorial, the government and the DAAH, an official people who works with transporters, cell phone, satellite phone...

- To keep contact and work with Kabulis traders of inputs and of outputs. These links will easily permit to provide relevant information.

- To keep regular market price information for 2 or 3 outputs and 2 or inputs. To collect lots of goods information is the main risk that the project could not support

\footnotetext{
"Shepherd A., 1997. "Market information services and their problems". Collection Aliments dans les villes, FAO, juin 1997.

${ }^{7}$ Bridget Poon, 2001. "Guide to the Establishment of Market Information Services" FAO, October 2001.
} 
(Shepherd, 1997). For instance, outputs: the potatoes, the krout and one pulse with different varieties. Inputs: white urea, black urea, DAP with different quality.

It take skill to collects information the first time. As a matter of fact, the first contact with the market traders is decisive for the long term of partnership. That is why, the traders must get something out of it. That is why it is very important to analysis the traders strategies before dealing with them.

As the Yakawlang project is concerns, the steps are:

- the commercial exchange officer of the project must select some goods to study. According to the commercial exchange study, the potatoes, the krout and one pulse can be study as outputs, and white urea, black urea and DAP for the inputs.

- He must locate the market places in Kabul, in Bamyan and in Naka. He must regularly (promptly) put up the prices (relevant, reliant) of the above goods and take care about the variety of the outputs and the quality of the inputs. With cleverness, he must deal with the trader to keep contact for the next price put up.

- He must analysis the results and draw economic graph according to the year for understandable information (understandable, meaningful).

- He must select the best places (in the markets, in the mosque...) to present the economic information as well as the traders contacts (accessibility). He must go and visit the village to inform that the MIS is available and to remind MIS objectives.

- To up date economic data.

For a sustainable activity, the commercial exchange officer must to inform about his job and to select some (honest) people who agree to do this work. The MIS users could give the money for the transportation costs and/or the telecommunication.

\section{Advantages and disadvantages:}

The first advantage is to give information to the farmers and so more power to negotiate with the traders. Second, it must help the farmers to organize its sowing plan, to plant the appropriate crop variety, and to know where to sell. Third, the traders will suppose to get more regular outputs and the seasonality phenomenon will decrease if only storage capacity is developed.

The main problem is to broadcast the relevant and reliable information in time to the farmers. The local radio development is a strong tools which also could provide other information like hygiene, job opportunities etc.

The second issue concerns the difficulties to make link between the traders and the producers. That is why the MIS setting up must be presented as an economic tools which will give individual interest to everybody.

The third main problem would come from the transporters and the importexport traders in Kabul and in Pakistan who usually speculate with the potato and the currency rate exchange thanks to the seasonality phenomenon. Will they want to collaborate with the producers and the marketing officer of the project.

At last, the MIS development is a long term project and the first results could be seen after 2 or 3 years and it depends of the information broadcast quality. 


\section{Impacts of the MIS:}

The MIS will homogenise the some selected goods price with more transparency and so less unfair competition. Then, the farmers will improve their production plan according to the market trends and the relationships with the traders. At the end, the farmers will choose when they would like to sell and at which price. This would help them to better plan their household budget.

But the worst impact of the MIS will come when the farmers take the same decision at the same moment. In this case, the supply will increase significantly at the same period and so the price will fall down. The MIS will have the opposite effect that forecasted. That is why, the best is to create partnership between producers, shop keepers, transporters and traders to harmonize the supply-demand market. 


\subsection{Agreement between producers and traders}

Objective: to make professional relationships between traders, shop keepers, transporters and producers. To respond to the consumers demand (price, quality, quantity) thanks to agreements between traders and producers. To create traders/producers loyalty.

Given the agricultural potential (irrigated land, labour force, few pest and diseases etc) but the enclosing issue of Yakawlang district and its consequences (seasonality phenomenon), the agreement setting up between traders and producers, in one hand, will secure the traders market with production specification (quality, quantity, delay etc.), and in other hand, will permit to the producers to better plan their production and so the budget. The agreements setting up will decrease the output speculation.

Some recommendations before the agreement establishment:

- before the agreement establishment, the producers must know how the market works (price fluctuation, stakeholders, margin distribution, the market trends etc).

- the producers must be supported to calculate their production cost... to assess the land productivity and the labour productivity.

Advantages and disadvantages:

Building loyalty thanks to agreements will first help the farmers to plan their production according to the traders demand (quantity, quality, delay), second to discuss about the outputs prices and to find a adapted price for the consumers, the traders and the producers, third to innovate crop production according to the market trends observed by the traders (specific variety, new crops etc...).

But the main problems will come if the traders don't respect the agreement or will not to follow agreements whereas the farmers have invested in it. What are the juridical framework to control the agreement respect? Will the traders accept to be linked with farmers? To avoid this strong drawback, the traders could participate to the production mean costs of the farmers (for instance, to buy fertilizers, tools etc.). But, given the current dominating position and the individual behaviour of the traders, how to develop this concept?

Impact of the agreement establishment: 
Commercial exchanges study - Yakawlang district - April/May 2005

Solidarités

Several farmers will specialize in one or two crop productions whereas other would like to innovate thanks the agreement guarantee. The producers will enable better plan their household budget. At the end, the traders can also plan its sales and get loyalty consumers that they will appreciate.

59 


\section{Chronogram and monitoring}

\subsection{Chronograms}

Given the low cash availability and the will of the farmers (and the shop keepers) to be more independent about the commercial exchanges, and in order to reduce the farm production risks given the stakeholders connections, the 4 first proposed activities will be lead all together.

So the commercial exchange component must be understood as a global integrated item.

The appendix 1 presents the chronogram of the activities and the chronogram for the marketing officer of the project.

\subsection{Evaluation and Monitoring}

The commercial exchange component of the project must be evaluated in order to rectify the previous objectives and to respond to the farmers demand. As the matter of fact, the objectives are to improve and to strengthen the commercial exchanges.

This first evaluation (30 days) of the commercial exchange in the Yakawlang which permit to write this paper allow us to understand the elementary commercial exchanges, to analyse the stakeholders relationship and to propose some recommendations. But the commercial exchanges components of the rural development project must be evaluated and monitored during the 3 years project duration. The forecasted annual evaluations during the project may focus on the indicator study. This indicators are: 


\subsubsection{Individual and/or collective potato storage}

The objective is to strengthen the storage capacity of the potato:

\begin{tabular}{|c|c|c|c|c|}
\hline Objectives & $\begin{array}{l}\text { Suitable and } \\
\text { convenient } \\
\text { indicators }\end{array}$ & How to do & needs & Comments \\
\hline \multirow[t]{2}{*}{$\begin{array}{l}\text { To increase the } \\
\text { storage capacity } \\
\text { and the storage } \\
\text { quality of the } \\
\text { potato production }\end{array}$} & $\begin{array}{l}\text { loss } \\
\text { production } \\
\text { rate of each } \\
\text { beneficiary } \\
\text { (quantitative } \\
\text { and qualitatif } \\
\text { indicator) }\end{array}$ & $\begin{array}{l}\text { - To calculate the entering } \\
\text { potatoes data minus the } \\
\text { leaving potatoes. } \\
\text { - To evaluate the quality } \\
\text { with the farmer and to } \\
\text { compare with the } \\
\text { previous annual } \\
\text { production (to build a } \\
\text { quality scale) }\end{array}$ & $\begin{array}{l}\text { - A standard paper to } \\
\text { register the potatoes } \\
\text { production flux } \\
\text { - A extension officer to } \\
\text { control and centralize the } \\
\text { data } \\
\text { - A training for the farmers } \\
\text { to explain the importance } \\
\text { of this indicator } \\
\text { monitoring and to register } \\
\text { their own production }\end{array}$ & $\begin{array}{l}\text { The project manager } \\
\text { must organize a } \\
\text { training to the farmers } \\
\text { before the harvest time } \\
\text { about the indicator } \\
\text { monitoring. }\end{array}$ \\
\hline & \multicolumn{4}{|c|}{$\begin{array}{l}\text { Gain and interest over the objective: } \\
\text { - to evaluate the impact of the new storage technology to the potato production } \\
\text { (quantity/quality) } \\
\text { - to train the farmers to register and control their production (compatibility!!!) }\end{array}$} \\
\hline $\begin{array}{l}\text { To support the } \\
\text { farmers to sell } \\
\text { more potatoes } \\
\text { when the market } \\
\text { is not saturated }\end{array}$ & $\begin{array}{l}\text { Truck traffic } \\
\text { increasing } \\
\text { (quantitative } \\
\text { indicator) }\end{array}$ & $\begin{array}{l}\text { - To register the number } \\
\text { of truck of potatoes } \\
\text { which go out of } \\
\text { Yakawlang district. } \\
\text { - To observe the spreading } \\
\text { of the potato sale period. }\end{array}$ & $\begin{array}{l}\text { - an agreement with the } \\
\text { mayor of Yakawlang } \\
\text { district: to involve the } \\
\text { mayor who is responsible } \\
\text { of the market. He could be } \\
\text { trained to register the } \\
\text { truck traffic. }\end{array}$ & \\
\hline
\end{tabular}


Gain and interest over the objective:

- to involve the governor in the market management thanks to the mayor agreement

- to better understand the risk management of the farmers across the potato sale and the cash crop availability

- to observe the collective or individual approach of the farmers for the sale 


\subsubsection{Collective purchases and collective point depot}

The objective is to decrease the inputs purchases costs with bulk procurements:

\begin{tabular}{|c|c|c|c|c|}
\hline Objectives & $\begin{array}{l}\text { Suitable and } \\
\text { convenient } \\
\text { indicators }\end{array}$ & How to do & needs & Comments \\
\hline \multirow[t]{3}{*}{$\begin{array}{l}\text { To increase the } \\
\text { bulk purchases }\end{array}$} & $\begin{array}{l}\text { Number of } \\
\text { beneficiaries } \\
\text { who make } \\
\text { bulk } \\
\text { purchases } \\
\text { (quantitative } \\
\text { indicator) }\end{array}$ & $\begin{array}{l}\text { - To register the number } \\
\text { of farmers and the shop } \\
\text { keepers who make bulk } \\
\text { purchase thanks to } \\
\text { Solidarités approach }\end{array}$ & $\begin{array}{l}\text { - A training about the bulk } \\
\text { purchases impact } \\
\text { - To inform the farmers } \\
\text { about the storage } \\
\text { condition } \\
\text { - To train somebody about } \\
\text { the storage management. }\end{array}$ & \multirow{2}{*}{$\begin{array}{l}\text { The project manager } \\
\text { must organize a } \\
\text { training about benefits } \\
\text { of the bulk purchases to } \\
\text { the farmers at the } \\
\text { village level } \\
\text { It is important to } \\
\text { evaluate if the } \\
\text { beneficiaries are happy } \\
\text { about this service and to } \\
\text { evaluate their capacity } \\
\text { to take over this } \\
\text { component }\end{array}$} \\
\hline & $\begin{array}{l}\text { Number of } \\
\text { inputs } \\
\text { purchase per } \\
\text { farmers } \\
\text { (quantitative } \\
\text { indicator) }\end{array}$ & $\begin{array}{l}\text { - To calculate the average } \\
\text { of purchase bags of } \\
\text { inputs (white urea, black } \\
\text { urea, DAP etc. ) per } \\
\text { farmers according to the } \\
\text { farmers category }\end{array}$ & $\begin{array}{l}\text { - To build a farming system } \\
\text { typology } \\
\text { - A officer to inform the } \\
\text { village community about } \\
\text { the storage conditions }\end{array}$ & \\
\hline & \multicolumn{4}{|c|}{$\begin{array}{l}\text { Gain and interest over the objective: } \\
\text { - to evaluate the trust of the farmer with Solidarités } \\
\text { - to train the farmers to control and to plan their production costs } \\
\text { - to evaluate the capacity of the farmers to work together thanks to the village community }\end{array}$} \\
\hline
\end{tabular}




\subsubsection{Proximity loan system}

The objective is to provide a loaning services to the farmers and the shop keepers. This component must be realized with an organisation which are already experimented with the loaning system and which.

\begin{tabular}{|c|c|c|c|c|}
\hline Objectives & $\begin{array}{c}\begin{array}{c}\text { Suitable and } \\
\text { convenient } \\
\text { indicators }\end{array} \\
\end{array}$ & How to do & needs & Comments \\
\hline $\begin{array}{l}\text { To set up the loan } \\
\text { system access to } \\
\text { the farmers and } \\
\text { the shop keepers. }\end{array}$ & $\begin{array}{l}\text { Number of } \\
\text { beneficiaries } \\
\text { who make } \\
\text { loan to the } \\
\text { loan system } \\
\text { service } \\
\text { (quantitative } \\
\text { indicator) } \\
\text { Determination } \\
\text { of the loaning } \\
\text { project of the } \\
\text { beneficiaries } \\
\text { (qualitative } \\
\text { indicator) }\end{array}$ & $\begin{array}{l}\text { - To register the number } \\
\text { of farmers who make } \\
\text { loan } \\
\text { - To register the farmers } \\
\text { projects when they make } \\
\text { a loan. }\end{array}$ & $\begin{array}{l}\text { - To realize a partnership } \\
\text { with a specialized } \\
\text { organisation in the } \\
\text { loaning system }\end{array}$ & $\begin{array}{l}\text { The loan service } \\
\text { organisation which will } \\
\text { be responsible of the } \\
\text { loaning services setting } \\
\text { up must know the local } \\
\text { population of and make } \\
\text { Yakawlang and about the } \\
\text { study needs. } \\
\text { beneficiaries need }\end{array}$ \\
\hline & \multicolumn{4}{|c|}{$\begin{array}{l}\text { Gain and interest over the objective: } \\
\text { to analyse the loaning system demand of the farmers and so to evaluate the financial } \\
\text { needs of the region } \\
\text { to better grasp the beneficiaries demands thanks to the farmers project thanks to the } \\
\text { loaning }\end{array}$} \\
\hline
\end{tabular}




\subsubsection{Market information services (M.I.S.)}

The objective is to provide a better visibility of the prices to help the farmers and the shop keepers to reach better decisions for sale.

\begin{tabular}{|c|c|c|c|c|}
\hline Objectives & $\begin{array}{l}\text { Suitable and } \\
\text { convenient } \\
\text { indicators }\end{array}$ & How to do & needs & Comments \\
\hline \multirow[t]{3}{*}{$\begin{array}{l}\text { To build a MIS in } \\
\text { Yakawlang }\end{array}$} & $\begin{array}{l}\text { Number of } \\
\text { beneficiaries } \\
\text { who visit the } \\
\text { MIS board. } \\
\text { (quantitative } \\
\text { indicator) }\end{array}$ & $\begin{array}{l}\text { - To register the number } \\
\text { of farmers who go and } \\
\text { visit the MIS board and } \\
\text { to ask them when they } \\
\text { would like to sell and/or } \\
\text { buy their production }\end{array}$ & \multirow{2}{*}{$\begin{array}{l}\text { - An extension officer for } \\
\text { the villages visit }\end{array}$} & \multirow[t]{2}{*}{$\begin{array}{l}\text { To improve the } \\
\text { information circulation } \\
\text { with the radio Bamyan } \\
\text { station }\end{array}$} \\
\hline & $\begin{array}{l}\text { Spreading of } \\
\text { the } \\
\text { information of } \\
\text { the existing } \\
\text { MIS } \\
\text { (qualitative } \\
\text { indicator) }\end{array}$ & $\begin{array}{l}\text { - To visit and survey the } \\
\text { villagers in different } \\
\text { villages about the } \\
\text { existing MIS }\end{array}$ & & \\
\hline & \multicolumn{4}{|c|}{$\begin{array}{l}\text { Gain and interest over the objective: } \\
\text { - to analyse the loaning system demand of the farmers and so to evaluate the financial } \\
\text { needs of the region } \\
\text { - to better grasp the beneficiaries demands thanks to the farmers project thanks to the } \\
\text { loaning }\end{array}$} \\
\hline
\end{tabular}




\subsubsection{Agreement between producers and traders}

The objective is to improve the commercial exchanges between the traders and the farmers with official and loyalty connection.

\begin{tabular}{|c|c|c|c|c|}
\hline Objectives & $\begin{array}{c}\text { Suitable and } \\
\text { convenient } \\
\text { indicators }\end{array}$ & How to do & needs & Comments \\
\hline \multirow[t]{3}{*}{$\begin{array}{l}\text { To develop the } \\
\text { loyalty commercial } \\
\text { exchanges }\end{array}$} & $\begin{array}{l}\text { Number of } \\
\text { agreement } \\
\text { between } \\
\text { traders and } \\
\text { producers. } \\
\text { (quantitative } \\
\text { indicator) }\end{array}$ & $\begin{array}{l}\text { - To have regular contact } \\
\text { with traders } \\
\text { (quality indicator) }\end{array}$ & \multirow{2}{*}{$\begin{array}{l}\text { - An extension officer who } \\
\text { make the relationship } \\
\text { between the traders and } \\
\text { the farmers and the shop } \\
\text { keepers } \\
\text { - An extension officer to } \\
\text { inform the producers } \\
\text { about the traders } \\
\text { demands have easy } \\
\text { - To access } \\
\text { telecommunication } \\
\text { (cell phone, thurya, } \\
\text { radio...) }\end{array}$} & \\
\hline & $\begin{array}{l}\text { Number of } \\
\text { agreement } \\
\text { about specific } \\
\text { outputs } \\
\text { (qualitative } \\
\text { and } \\
\text { quantitative } \\
\text { indicator) }\end{array}$ & $\begin{array}{l}\text { - To discuss about what } \\
\text { are their demands } \\
\text { (product, } \\
\text { quality/quantity) } \\
\text { (quality indicator) }\end{array}$ & & \\
\hline & \multicolumn{4}{|c|}{$\begin{array}{l}\text { Gain and interest over the objective: } \\
\text { - to analyse the loaning system demand of the farmers and so to evaluate the financial } \\
\text { needs of the region } \\
\text { - to better grasp the beneficiaries demands thanks to the farmers project thanks to the } \\
\text { loaning }\end{array}$} \\
\hline
\end{tabular}




\section{Appendix:}

Appendix 1: Chronograms

Appendix 1.1: Activity framework

Appendix 1.2.: Daily workplan

Appendix 1.3.: Weekly workplan

Appendix 2: Maps

Appendix 2.1.: Map of the ethnic group

Appendix 2.2.: Geographic map of the Yakawlang district

Appendix 3: Production costs of pulses and potato productions

Appendix 4: Questionnaires

Appendix 4.1.: Farmers questionnaire

Appendix 4.2.: Shop keepers questionnaire

Appendix 5: List of the organization and authority which were met

Appendix 6: Itinerary 


\section{Bibliography}

\section{Marketing chain study:}

LASSALLE T., 1999. From production and distribution channels analysis to rural market development support. GRET. Training Programme Report-19 July 1999 - 30 July 1999, Maung Daw, North Rakhane State, Myanmar.

LAURET F., 1990. De l'utilisation de la notion de filière dans la recherche agroéconomique. In : \& Economie des filières en régions chaudes : formation des prix et échanges agricoles ", Actes du Xème séminaire d'économie et de sociologie, 11-15 septembre 1989.

SAUTIER D., CARON P., GAMA DA SILVA P, and al., 1998. Diagnostic rapide de la mise en marché. Le lait et ses dérivés dans une micro-région du Nord-Est du Brésil. In : Prix, produits, et acteurs. Méthode pour analyser la commercialisation agricole dans les pays en développement. Editions CIRAD-CIP-Karthala. 1998.

TERPEND N., 1997. Guide pratique de l'approche filière. Le Cas de l'approvisionnement et de la distribution des produits alimentaires des villes. Editions FAO, Collection "Aliments dans les villes ", DT/18-97F, 26p.

\section{Storage:}

http://www.fertilizer.org/ifa/

http://www.fertilizer.org/ifa/publicat/pdf/2002 fertilizer_retailing guide.pdf

\section{MIS:}

GALTIER F. \& EGG J.; 1998. Des dispositifs de diffusion de prix à des systèmes d'information de marché (SIM) à géométrie variable. Communication au colloque de l'AEEA, 23-26 septembre 1998, Wageningen. 21p.

SHEPHERD A., 1997; Market information services and their problems. Editions FAO, collection "Aliments dans les villes", DT/23/97 - juin 1997, 16p. 
http://www.fao.org/waicent/faoinfo/agricult/ags/AGSM/unmis/unmis.htm http://www.fao.org/waicent/faoinfo/agricult/ags/AGSM/mismanual.doc

\section{Proximity loan system:}

http://microfinancement.cirad.fr/fr/news/bim/Bim-2001/BIM-13-02-01.pdf http://microfinancement.cirad.fr/fr/news/sommaire-BIMS-1999-2004.htm http://www.agridoc.com/fichestechniques gret/services/Mise-enplace syst\%E8me financier rural FAFEC.pdf

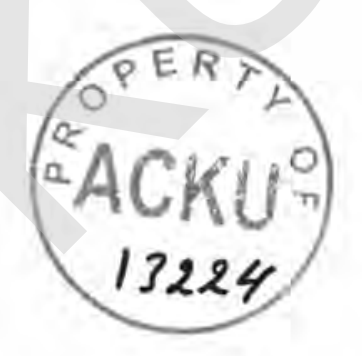


